Secuencia (2004), 60, septiembre-diciembre, 137-172 ISSN: 0186-0348, ISSN electrónico: 2395-8464 http://dx.doi.org/10.18234/secuencia.v0i60.884

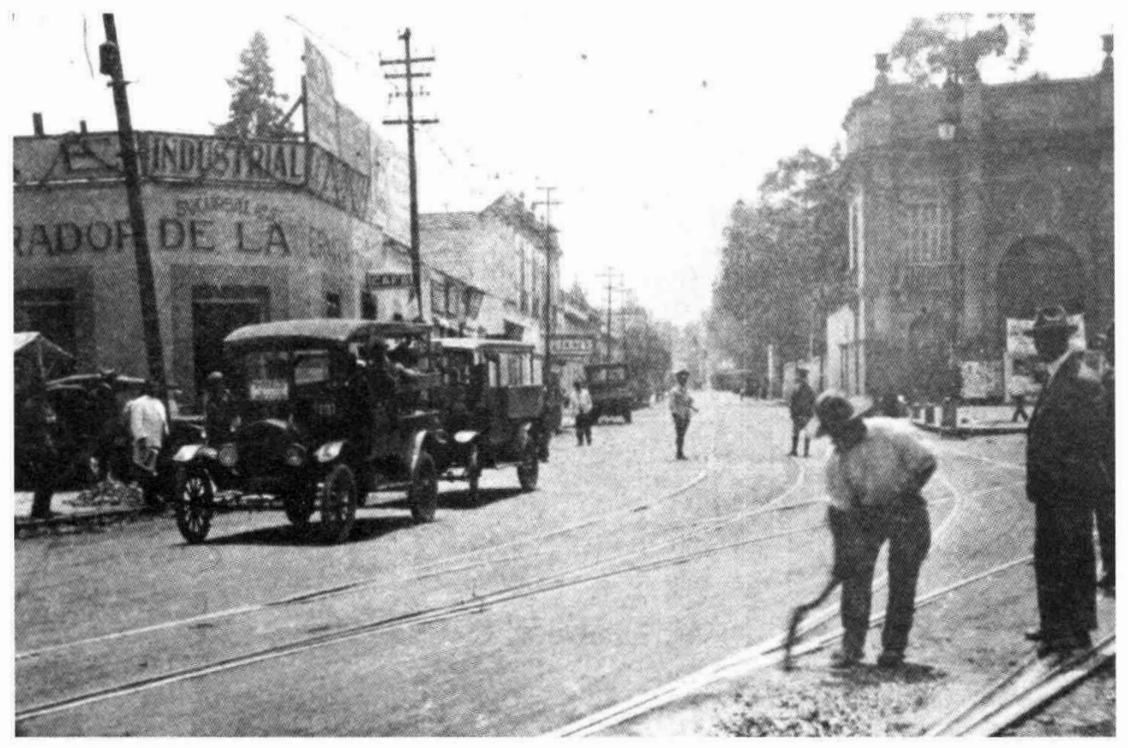




\section{Alberto del Castillo Troncoso}

Historiador. Egresado del doctorado en Historia del CEH de El Colegio de México. Miembro del Sistema Nacional de Investigadores. Catedrático desde hace quince años en la Escuela Nacional de Antropología e Historia, donde imparte un seminario de tesis sobre el tema de Historia de la fotografía en México. Investigador del Instituto Mora en el área de Historia Social y Cultural. Algunas publicaciones recientes: "La visión de los médicos y el reconocimiento de la niñez en el cambio del siglo XIX al xx", Boletín Mexicano de Historia y Filosofía de la Medicina, vol. 6, núm. 2, 2003; "El discurso científico y las representaciones en torno a la criminalidad en México en el cambio del siglo XIX al Xx" en Jorge A. Trujillo y Juan Quintar (coords.), Pobres, marginados y peligrosos, Universidad de Guadalajara/Universidad Nacional de Comahue, México, 2003.

\section{Resumen}

El presente artículo analiza las representaciones fotoperiodísticas del Movimiento Estudiantil de 1968 publicadas en el diario El Heraldo de México. Dicho análisis constituye una primera aportación a la historiografía del 68 realizada a partir de una historia gráfica que permite estudiar las imágenes de los fotógrafos como parte de una estrategia visual en la que deben considerarse la orientación política e ideológica del periódico en cuestión y su vinculación con el poder.

\section{Palabras clave:}

Fotoperiodismo, movimiento estudiantil, historia gráfica, pliego petitorio, estrategia visual.

\section{Abstract}

This article analyzes the photo-journalistic representations of the 1968 student movement in Mexico City, published in El Heraldo de Mexico. This analysis constitutes the first contribution to the historiography of ' 68 , carried out on the basis of a graphic history that enables one to study the photographers' images as part of a visual strategy in which the political and ideological orientation of the newspaper in question and its link with power should be considered.

\section{Key words:}

Photojournalism, student movement, graphic history, list of demands, visual strategy.

Fecha de recepción:

noviembre de 2003

Fecha de aceptación: abril de 2004 


\title{
Fotoperiodismo y representaciones del Movimiento Estudiantil de 1968. El caso de El Heraldo de México*
}

\author{
Alberto del Castillo Troncoso
}

DE LA HISTORIA DE LA FO'TOGRAFÍA A LA DEL FOTOPERIODISMO

$\mathbf{E}$ l estudio de la fotografía ha sido incorporado al análisis de la investigación histórica desde hace varias décadas, consolidándose un campo que ha sido denominado "historia gráfica" que plantea básicamente la necesidad de que las imágenes fotográficas dejen de ser consideradas como una simple ilustración de los discursos escritos y que comiencen a ser valoradas desde una perspectiva más compleja, atendiendo a la lectura e interpretación de sus contenidos específicos. ${ }^{1}$

La historia gráfica no se limita a una puesta en escena de las imágenes o a su mera vinculación a un periodo determinado, como podría ser el caso de una historia ilustrada. Por el contrario, su propósito es más complejo y consiste en desarrollar un análisis, una lectura y una interpreta-

* Agradezco al investigador John Mraz, a los fotógrafos Luis Jorge Gallegos y Rodrigo Moya, y a mis queridos colegas del seminario de Historia Social y Cultural del Instituto Mora: Cristina Sacristán, Verónica Zárate, Javier Rodríguez, Ma. Eugenia Chaoul, Ma. Esther Pérez-Salas, Ma. Jose Garrido, Mónica Szurmuk, Laura Suárez y Gerardo Morales, sus comentarios y observaciones para la realización de este trabajo.

1 Sobre el término historia gráfica, véase Mraz, "Historiografía", 1998, pp. 77-92. ción del discurso visual cotejando las imágenes con todo tipo de documentación escrita y no escrita, asequible a la historia social y cultural. Esta línea de trabajo ha comenzado a producir aportaciones sólidas e importantes para la historiografía latinoamericana y mexicana. Sin embargo, puede considerarse todavía como un área marginal de la misma, con un desarrollo precario e incipiente.

En el campo de la historia del fotoperiodismo mexicano ha predominado el seguimiento más o menos puntual en torno a la obra de algunos fotógrafos, considerados como referencias autorales básicas para comprender la evolución de la prensa gráfica en nuestro país a lo largo del siglo $\mathrm{xx}$. Tal es el caso de los fotógrafos y reporteros Agustín Víctor Casasola y Enrique Díaz, en lo que concierne a la revolución mexicana y a los primeros regímenes emanados de la misma, o de Juan Guzmán, los hermanos Mayo, Héctor García, Rodrigo Moya y Nacho López, vinculados al quehacer fotoperiodístico en las siguientes décadas. El estudio de su obra nos ha permitido acercarnos a algunos aspectos relevantes de la política, de la sociedad y de la cultura de la época, no contemplados por los estudios históricos tradicionales, tales como la nota roja y los reportajes policiacos, la cara no oficial del 
indigenismo, las precarias condiciones de vida de los migrantes, algunos aspectos destacados de los movimientos sociales y los rostros concretos de la pobreza urbana, entre muchas otras cuestiones desarrolladas por la lente de estos profesionales. Sin embargo, resulta evidente la ausencia de este tipo de trabajos en lo que se refiere a la segunda mitad del siglo $\mathrm{XX} .^{2}$

EL MOVIMIENTo ESTUDIANTIL DE 1968 A 35 AÑOS DE DISTANCIA

El Movimiento Estudiantil de 1968 ha sido estudiado desde diversos ángulos durante las últimas tres décadas. Cuenta con una historiografía política, social y cultural que tiende a incrementarse en los últimos años, en los que se ha acentuado su relevancia en torno al peso simbólico asignado a su incidencia en el proceso de democratización de la sociedad y del Estado. $^{3}$

Existe un consenso entre los especialistas en destacar como parte nodular del movimiento la reivindicación de las libertades civiles y la defensa del Estado de derecho. En este sentido, cabe señalar su carácter antiautoritario ante los límites y la rigidez del sistema político mexicano, en un contexto en el que se produjeron rebeliones estudiantiles en distintos lugares del planeta, desde las ciudades de San Francisco y Nueva York en Estados

\footnotetext{
${ }^{2}$ Mraz, Nacho, 1999; Monroy, Historias, 2003; González, "Juan", 2003; Casanova, Castellanos y Moya, Rodrigo, 2002; Mraz, Mirada, 1998.

${ }^{3}$ González, Diálogos, 2003. Esta obra cita más de 250 referencias importantes, entre obras de consulta, textos literarios, testimonios, grabaciones, catálogos y páginas de Internet.
}

Unidos, hasta las capitales más importantes de Europa, como París, Roma, Londres, Berlín y Praga, y otros centros urbanos disímbolos entre sí, como Tokio, Toronto y Río de Janeiro. Todo ello proporciona una perspectiva global que debe tomarse en cuenta en el momento de abordar la especificidad del proceso estudiantil mexicano:

Son variadas las causas que han querido hallarse para explicar la efervescencia de la revolución juvenil en los sesenta: la relativa abundancia económica de la posguerra, el renovado interés por la espiritualidad, la expansión de los sistemas universitarios, la deshumanización tecnológica, la influencia de ídolos pop y de algunos pensadores - de los Beatles a Marcuse-, la brecha entre padres e hijos y, desde luego, la oposición a la guerra de Vietnam. Lo cierto es que un conjunto vasto de factores, presentes en la política internacional desde el fin de la guerra, desató una reacción en cadena; de pronto, causas que en otro momento hubieran pasado inadvertidas provocaron efectos devastadores en la sociedad posindustrial. ${ }^{4}$

Los protagonistas de los hechos han resaltado la participación del rector de la Universidad Nacional Autónoma de México (UNAM), Javier Bartios Sierra, quien unificó a los diversos grupos dentro de la UNAM y posibilitó la formación del Consejo Nacional de Huelga (CNH), el órgano fundamental que aglutinó a las escuelas y facultades del Instituto Politécnico Nacional y de la UNAM. Gilberto Guevara Niebla ha descrito el caos y el desorden prevaleciente entre los distintos grupos en el interior de la UNAM a finales de julio del

$$
{ }^{4} \text { Volpi, Imaginación, 1998, p. } 154 .
$$


68, aportando el siguiente testimonio, vital para reconstruir la atmósfera de la época, y comprender la lógica de los dirigentes del movimiento:

En esos momentos, en San Ildefonso, el ejército derribaba la puerta de un bazucazo. El martes 30 hubo un mitin frente a la Rectoría, en el cual Barros Sierra izó la bandera a media asta, pues la Universidad estaba de luto. Raúl Álvarez Gatín se encontraba en Oaxtepec, en un congreso de matemáticas. El 30 por la tarde nos reunimos y advertimos que las iniciativas del rector abrían una perspectiva política pues objetivamente contrariaban la línea represiva del gobierno. ${ }^{5}$

La cronología del movimiento del 68 es ampliamente conocida, desde la pelea en la Ciudadela entre estudiantes de la escuela Isaac Ochoterena y los de la Vocacional 2 del Politécnico y la consecuente represión por parte de los granaderos el 22 de julio hasta la matanza del 2 de octubre en Tlatelolco y sus secuelas. El movimiento estudiantil vivió sus mejores momentos entre el 5 de agosto y el 13 de septiembre de 1968. En ese breve lapso se produjo una protesta civil pacífica y multitudinaria que se apropió del espacio público de una manera festiva $y$ puso en jaque al poder autoritario que prevalecía en México, representado por la figura del ejecutivo y por la hegemonía de un partido, el Revolucionario Institucional, que había gobernado el país durante las últimas cuatro décadas.

Por parte de las autoridades, prevaleció la idea de una teoría de la conjura característica del esquema político-cultural dominante de la guerra fría, según

${ }^{5}$ Guevara, "Nace", 1988, p. 53. el cual, oscuras fuerzas locales e internacionales de carácter comunista conspiraban para desestabilizar al país y provocar una revolución. ${ }^{6} \mathrm{La}$ estrategia dispuesta para enfrentar este peligro fue la puesta en escena de un plan político-militar que utilizó todos los recursos a su alcance para provocar la violencia y reprimir al movimiento estudiantil:

La familia revolucionaria mexicana está dotada con una misión. No se considera una representante del pueblo, sino su guía, su líder. A ella le corresponde la inmensa tarea de sacar al pueblo de su ancestral atraso e ignorancia para encaminarlo hacia el progreso [...] El movimiento del 68 fue visto y explicado como una conspiración. La conspiración nunca estuvo más de moda. No se probó su existencia, pero tampoco se necesitaba prueba [...] La familia formada para la conspiración no podía creer lo obvio: que un sector de la sociedad se movilizara con autonomía y por su propia iniciativa. No podía creerlo por razones poderosas: si eso

6 "Lo particular de la visión paranoica de la historia es su creencia de que las conspiraciones son la fuerza motriz de la historia y el principio organizativo básico de la política. Para ellos, la conspiración existe, avanza rápidamente y es malévola por definición. La victoria de los conspiradores está siempre cerca y, por ende, el paranoico personifica el bien y es el encargado de enfrentarse a ellos." Aguayo, 1968, 1998, p. 38. Cientos de fichas de identidad de los protagonistas del movimiento estudiantil, elaboradas por agentes de gobernación, parecen corroborar el planteamiento anterior, al mostrar a los líderes como peligrosos conspiradores y terroristas, con estrechos vínculos con La Habana y Moscú, cuya finalidad consistía en sabotear la celebración de las olimpiadas, desprestigiar el régimen de Díaz Ordaz e instaurar un gobierno de carácter socialista. Al respecto, véase Espinoza, "Fichas", 2003, pp. 26-30. 
fuera posible su misión trascendente y civilizadora para llevar al pueblo a la verdadera democracia carecería de sentido, se habría vuelto redundante. ${ }^{7}$

En términos generales, coincidimos con Guevara Niebla en su caracterización del 68 cuando señala que:

Se trata, en realidad, de un conflicto social en el cual, siendo el estudiantado el agente principal, convergen y coagulan procesos sociales de muy diverso orden que habían venido gestándose a lo largo de la época precedente. $^{8}$

\section{FOTOPERIODISMO Y MOVIMIENTO ESTUDIANTIL DE 1968}

El fotoperiodismo generado en torno al Movimiento Estudiantil de 1968 en la ciudad de México construyó un imaginario colectivo, ${ }^{9}$ elaborado a partir de intereses diversos de reporteros, periodistas y fotógrafos pertenecientes a publicaciones que abarcaron un amplio espectro, que, por lo general, estuvo subordinado a posturas oficialistas, pero que también abarcó -si bien de manera marginal- visiones críticas y contestatarias. Las características del fotoperiodismo mexicano y sus complejas relaciones de poder con la so-

${ }^{7}$ Warman, "Secreto", 1988, p. 133.

${ }^{8}$ Guevara, Democracia, 1998, p. 45.

9 "El campo de lo imaginario está constituido por el conjunto de representaciones que desbordan el límite trazado por los testimonios de la experiencia y de los encadenamientos deductivos que éstos autorizan. Lo que significa que cada cultura y por tanto cada sociedad e incluso cada nivel de una sociedad compleja tiene su imaginario." Patlagean, "Historia", 1984, p. 247. ciedad y el Estado pueden observarse de una manera privilegiada en el análisis y en el seguimiento puntual del discurso visual construido por los fotógrafos a partir de la cobertura de movimientos sociales amplios con una presencia nacional, como es el caso de la revuelta estudiantil de 1968.

En dicha cobertura se puede apreciar tanto la evolución temática y estilística de los autores, como, sobre todo, su forma de plantear una "estrategia visual", vinculada a la argumentación política y cultural de la época, la cual no constituye un mero reflejo de los textos escritos, sino que incide sobre éstos y amplía notablemente la perspectiva de análisis de los problemas sociales. En todo momento tomaremos en cuenta que dicha estrategia no es obra exclusiva de los fotógrafos, sino que debe entenderse a partir de la tensión generada entre el autor de la imagen y el lugar y el espacio que ocupa ésta dentro de la publicación periodística correspondiente, que le imprime una orientación ideológica específica, entre otras cosas, a partir del pie de foto. ${ }^{10}$

A finales de la década de los sesenta predominaba en México un esquema autoritario con una censura generalizada que se manifestaba en un control del contenido informativo de los diarios. Este esquema ha sido descrito en un ensayo reciente por Luis González de Alba, uno de

${ }^{10}$ Un caso muy importante al respecto es el de la revista Tiempo, dirigida en 1968 por el escritor Martín Luis Guzmán, que mantuvo una postura oficialista y de rechazo al movimiento estudiantil. En contraste, las imágenes fotográficas de la revista corrieron a cargo de los hermanos Mayo, de reconocida trayectoria izquierdista. La clave de la cuestión estriba en los pies de foto, que previsiblemente se encargaron de satanizar a los estudiantes. 
los líderes del movimiento estudiantil del 68 de la siguiente manera:

Para dar una idea, aunque sea somera, de la enorme diferencia entre los años en que mi generación tenía 20 años y la que hoy tiene esa edad, creo que me bastará con señalar unos cuantos elementos: la única fuerza política era la del PRI y en este partido la única fuerza era la del presidente de la república; toda la prensa era idéntica porque repetía simplemente los boletines oficiales de cada dependencia, así que ni siquiera la redacción de la misma noticia variaba mucho. ${ }^{11}$

En el campo del fotoperiodismo dicho esquema implicaba un escaso reconocimiento a los fotógrafos y un espacio muy reducido para el ejercicio de la creatividad. En la mayor parte de los casos, la fotografía era utilizada para ilustrar la nota correspondiente y, en un buen porcentaje de éstos, las imágenes aparecían publicadas sin el crédito del autor.

En términos generales, las órdenes de trabajo para los fotógrafos suponían un número limitado de imágenes y una línea editorial bastante estricta, a la cual había que supeditarse. Una de las consecuencias previsibles de todo esto fue la ausencia de espacio para la experimentación y la creatividad, así como la subordinación a las convenciones visuales dominantes. Pese a todo, existieron excepciones importantes, como el periódico Excélsior, el cual, en aquella época, figuraba entre los diarios más importantes de América Latina, y que para el caso del movimiento estudiantil del 68 desarrolló una reflexión periodística significativa, con fotógrafos como Rafael Escoto, Miguel Castillo, Carlos

${ }^{11}$ González de Alba, Mentivas, 2002, p. 89.
González y Jaime González y analistas críticos como Daniel Cosío Villegas.

Por su parte, La Cultura en México, suplemento de la revista Siempre!, dirigido por Fernando Benítez, contó entre sus colaboradores con Carlos Monsiváis y José Emilio Pacheco, lectores atentos no sólo a los episodios locales, sino al desarrollo de los movimientos estudiantiles en Francia, Estados Unidos y Europa del Este. ${ }^{12}$

El semanario en cuestión publicó en el mes de septiembre un conjunto de fotografías atribuidas fundamentalmente a Héctor García, las cuales ilustraron los distintos artículos que abordaban la temática del movimiento estudiantil y posicionaron a este autor como una de las referencias más importantes del movimiento. ${ }^{13}$

Un análisis de contenido de una selección de noticias y textos publicados en la prensa del 68 realizado recientemente aporta los siguientes resultados. Una revisión de los periódicos distingue dos bloques muy bien diferenciados: el prime-

${ }^{12}$ De una manera más marginal, el semanario sensacionalista ¿Por qué?, dirigido por Mario Menéndez, representó otra referencia crítica e independiente del punto de vista oficial.

${ }^{13}$ La Cultura en México, núm. 345, suplemento de la revista Siempre! El título de este importante número fue: "Lo que se ha visto y lo que se ha dicho. Una versión del movimiento estudiantil. Fotos y textos de antología. 23 de julio a 17 de septiembre." En torno a la obra de Héctor García durante el 68 se ha destacado el hecho de que algunas de sus fotografías parecen formar parte de una estrategia del autor, que consiste en plasmar movimiento dentro del encuadre, como aquélla en la cual retrata a los estudiantes como fantasmas entrando al Zócalo durante la marcha silenciosa del 13 de septiembre, o la más famosa de todas, en la que un soldado apunta con su fusil a una familia en la unidad de Tlateloico, en pleno 2 de octubre. 
ro, representado por los periódicos Excélsior y El Día, muestra una ligera defensa del movimiento estudiantil, que se refleja en 48 y $57 \%$ de notas publicadas en favor, respectivamente. Por el otro lado, tenemos los periódicos El Sol de México, El Universal, Novedades y El Heraldo, con $100,79,59$ y $56 \%$ de notas y artículos en contra. Lo anterior nos proporciona un primer marco de referencia para analizar las imágenes fotográficas de los diarios. ${ }^{14}$

En otro campo temático, cabe señalar la importancia de algunos diarios cercanos a la "nota roja" y al reportaje policiaco, tales como La Prensa, Alarma y Magazine de Policía. Este último desarrolló algunos de los reportajes gráficos más extensos sobre el movimiento estudiantil con una visión crítica en torno a la represión llevada a cabo por el cuerpo de granaderos. Dichos reportajes fueron realizados por los fotógrafos Julio León, Aarón Sánchez, Miguel Castillo, Ignacio Castillo, Luis Rodríguez, José Carmona, Jesús de la Torre, Gustavo Vargas y el ya citado Jaime González. Hasta el momento no han sido analizados desde la perspectiva de una historia de la fotografía del periodo. ${ }^{15}$

${ }^{14}$ Cano, "Libros", 2003 , pp. 115-130. Por lo que respecta al periódico El Día, de orientación priista, cabe recordar la renuncia del coordinador de información internacional, José Carreño, junto con numerosos reporteros y colaboradores que tomaron distancia del sesgo gubernamental con el que el periódico justificaba la represión policiaca contra los estudiantes a principios de agosto del 68. Lo anterior constituye una muestra más de la imposibilidad de acercarse a la prensa como un bloque monolítico, $\sin$ fisuras, matices y contradicciones.

is Debe agregarse en este campo el trabajo de Brocca, Nota, 1993, el cual incorpora las notas periodísticas sobre el 68 al espacio de la nota roja. La investigación de la autora se centra en los textos y deja de
En este contexto, algunas de las preguntas y temas que vale la pena preguntarse para la construcción de una posible historia gráfica en torno al movimiento estudiantil son las siguientes: la relación profesional de los fotógrafos con los medios de comunicación; el grado de censura y de autocensura, implícita y explícita prevaleciente tanto en la construcción de los textos como de las imágenes fotográficas; las características del discurso visual construido por dichos medios; las referencias culturales y la cultura visual de los fotorreporteros; el uso y la manipulación de las fotografías a través de la diagramación y el ejercicio editorial de los diarios; el impacto de las imágenes como parte de la construcción de un imaginario colectivo en torno al movimiento estudiantil dirigido a la opinión pública de la época; los distintos grados de recepción por parte de distintos sectores sociales en general y por parte de los líderes y protagonistas de los movimientos estudiantiles en particular, y la apropiación o el rechazo de algunas imágenes por parte de los líderes y el grado de incidencia de éstas en la conformación y estrategia de dichos movimientos.

En cuanto a los textos con información fotográfica, se han publicado importantes trabajos a lo largo de estas tres décadas. Sin embargo, la perspectiva de una historia gráfiça ha estado ausente en una buena parte de los análisis, lo que evidencia la necesidad de impulsar este tipo de investigaciones,

lado las imágenes. De hecho, sólo aparece una fotografía sin crédito que se refiere a la entrada del ejército al Zócalo a finales de agosto, y aun esta imagen es utilizada como simple ilustración de los planteamientos del texto. 
que recuperen la enorme riqueza del discurso visual producido por reporteros y fotógrafos. ${ }^{16}$

En respuesta a los planteamientos anteriormente expuestos, en el presente texto analizaremos de qué manera se fue construyendo el movimiento estudiantil a partir de algunos medios, buscando argumentar hasta qué punto la información gráfica sólo respondió a una puesta en escena de los deseos de control y manipulación del gobierno y su teoría de la conjura, y hasta dónde se abrieron también otros espacios alternos de crítica a partir de la imagen. Al respecto, resulta muy significativo que la reflexión autobiográfica de uno de los líderes más importantes del movimiento del 68 , el ya mencionado Raúl Álvarez Garín, titulada: La estela de Tlatelolco, publicada 30 años después de los acontecimientos, incluya en la parte final del texto una antología de imágenes con el título: "Reconstrucción gráfica del movimiento estudiantil", la cual consta de 76 fotografías, de las cuales el autor no dice una sola palabra. Lo anterior proporciona al lector una idea del enorme vacío en términos de análisis gráfico al que nos estamos enfrentando.

\section{LA LECTURA DE LAS IMÁGENES. El CASO de El HERALDO DE MÉXICO}

En este artículo nos referiremos en forma exclusiva a El Heraldo de México, vocero

${ }^{16}$ La lista de textos literarios y académicos que abordan el tema del movimiento del $68 \mathrm{e}$ incluyen fotografías es muy extensa. No es éste el espacio idóneo para comentar estos trabajos, que formarán parte de otra investigación. de un importante grupo empresarial, referencia obligada para evaluar el punto de vista de algunos sectores patronales y su relación con el poder presidencial. ${ }^{17}$

\section{La relación prensa-poder}

El Heraldo de México fue fundado en 1965. Impreso en offset, a colores, desde sus inicios contó con una infraestructura moderna, con grandes recursos financieros y técnicos. Vocero de un poderoso grupo de empresarios y banqueros poblanos, su director fue Gabriel Alarcón, que tuvo una importante cercanía con el presidente Gustavo Díaz Ordaz, prácticamente desde el primer número del diario:

En la primera plana de su edición inicial, El Heraldo publicó una foto de gran tamaño del presidente Díaz Ordaz, en el momento de inaugurar las instalaciones del diario y declararse su "primer lector". Díaz Ordaz dedicó a Gabriel Alarcón frases elogiosas. ${ }^{18}$

Una de la característica distintiva de este periódico es la gran importancia que desempeñaron las imágenes dentro de su política editorial, la cual las concebía no sólo como un complemento para la divulgación de las noticias y de los reportajes, sino como una parte importante de la

${ }^{17} \mathrm{La}$ lectura de imágenes de El Heraldo de México que propongo en este artículo constituye un primer avance de una investigación más amplia en torno al fotoperiodismo y el Movimiento Estudiantil de 1968 que actualmente desarrollo en el Instituto Mora y que abarcará los principales periódicos de la época. Agradezco a Mónica Flores sus valiosos comentarios y su apoyo en la localización de las imágenes para el presente artículo.

${ }^{1.8}$ Rodríguez, Prensa, 1993, p. 101. 
postura política del propio diario. La Cobertura gráfica asignada al 68 documenta puntualmente esta aseveración. Un importante grupo de fotógrafos cubrió regularmente los acontecimientos, de tal manera que en algunos episodios llegaron a desarrollarse reportajes gráficos de alrededor de 30 imágenes, las cuales eran publicadas tanto en la primera plana como en las páginas intermedias. A diferencia de una buena parte de la prensa de la época, El Heraldo proporcionó el crédito correspondiente a sus fotógrafos, aunque éste se asignaba de manera general, en referencia a la totalidad del reportaje en cuestión. La lista de autores mencionados a lo largo de los tres meses de duración del movimiento son Ramón Guzmán, Gustavo Guardiola, Ernesto Valenzuela, Eduardo Quiroz, Ismael Casasola, Enrique Flores, Porfirio Cuautle, Carlos Arroyo, Arturo Flota, Gustavo Flores, Guillermo Ávila, Andrés Manzanares, Carlos Villagrán, Raúl Sosa, Rafael Castellanos, José Pereda y José Aguilar. ${ }^{19}$

El análisis que desarrollamos en este artículo se apoya en este planteamiento básico que sostiene que el manejo de las fotografías fue prioritaria dentro de la estrategia informativa y persuasiva del periódico. Un episodio ocurrido a finales de agosto parece corroborar este punto y vale la pena revisarlo desde la perspectiva de la relación de la prensa con el poder. El 27 de agosto tuvo lugar la manifestación más concurrida del movimiento, calculada en unos 300000 estudiantes. Este importan-

${ }^{19}$ El 25 de enero de 1970 fallecieron en un avionazo, cubriendo la campaña de Luis Echeverría, candidato del PRI a la presidencia, los fotógrafos: José Falconi, Ismael Casasola y Eduardo Quiroz, quien para entonces era el jefe del departamento de fotografía. te momento marcó la cúspide del proceso de organización estudiantil, así como la reconsideración gubernamental de un mayor control de los medios. Dicha multitud abarrotó el Zócalo, concluyó el enorme mitin convocado por el CNH y dejó una guardia de 3000 personas afuera de Palacio Nacional, en un intento por presionar a las autoridades para la realización de un diálogo público, a sugerencia de Sócrates Amado Campos Lemus, uno de los líderes del citado Consejo. Posteriormente fue dispersada por la policía y por el ejército en la madrugada.

Al día siguiente, el astabandera de la Plaza portaba una especie de jerga de color rojinegro en lugar del tradicional lábaro patrio. $\mathrm{El}$ acto fue de inmediato atribuido a los estudiantes y calificado como un agravio a la nación. Este episodio se convirtió en piedra angular de un ejercicio sistemático de descalificación del movimiento. Un día más tarde, se organizó un acto de desagravio oficial en el que fueron acarreados cientos de burócratas y empleados del Gobierno del Distrito Federal y que consistió en volver a izar la bandera en el Zócalo. La publicación en primera plana de las declaraciones de Gustavo Díaz Ordaz sintetizaban el hecho y le imprimían una lectura cívica a las imágenes publicadas en el diario: "Sólo la bandera de México, dijo Díaz Ordaz." Por su parte, El Heraldo ampliaba la lección con otro titular bastante significativo: "Prefirieron el trapo rojinegro en lugar de la enseña patria" (véase imagen 1). ${ }^{20}$

${ }^{20}$ El Heraldo de México, 29 de agosto de 1968, 1a. plana. La provocación de Campos Lemus ha sido ampliamente comentada por los otros líderes del $\mathrm{CNH}$, presentes esa noche en el Zócalo y ha sido catalogada como un grave error político, que facilitó la 


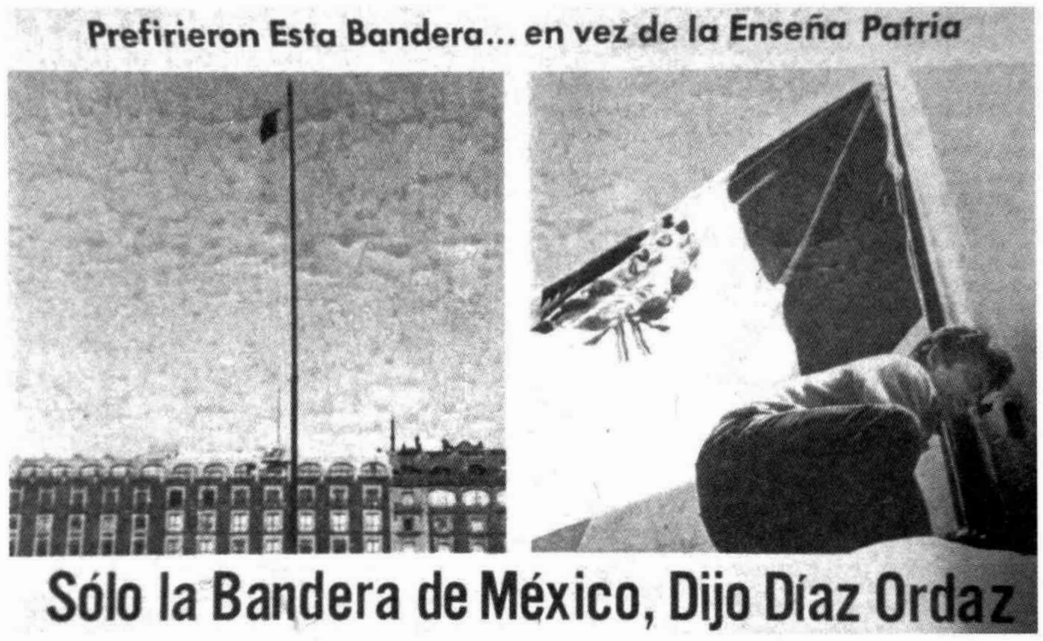

Imagen 1. "Los estudiantes prefirieron la bandera rojinegra al pendón nacional y anteanoche la izaron en la Plaza de la Constitución; pero ayer al medio día, el pueblo, entonando el Himno Nacional, volvió a elevar el mayor símbolo de la patria en su asta del Zócalo", El Heraldo de México, 29 de agosto de 1968, en Archivo Histórico de la UNAM-CESU.

Varias fotografías documentaron el episodio con una fuerte carga simbólica. Primero la imagen del astabandera con la bandera rojinegra. Posteriormente el contraste entre la imagen de ésta y la del lábaro patrio, y, para finalizar, otro par de fotografías que muestran la reacción épica

propaganda gubernamental de desprestigio a través de los medios y anuló parcialmente el efecto psicológico de la manifestación. En lo que respecta al episodio del agravio al lábaro patrio, Cabeza de Vaca, el líder del CNH señalado por el gobierno como autor del incidente, ha negado en repetidas ocasiones haber izado el asta con el trapo rojinegro y en cambio sugiere que fue obra de las autoridades. Para efectos prácticos, lo que contó políticamente fue la constatación del hecho y su utilización por parte de la prensa. del pueblo que rescata su bandera. El ambiente es festivo y pueden observarse los rostros de los empleados y oficinistas gubernamentales convertidos por el arte del civismo en héroes anónimos. La utilización del color resalta el mensaje patriótico de todo el episodio. De esta manera, los pliegues del lábaro patrio contribuyen a una idea de estar presenciando una escena salida de un mural o un fresco revolucionario (véase imagen 2).

Una carta de Gabriel Alarcón, director de El Heraldo, dirigida al presidente Díaz Ordaz, dada a conocer recientemente, resume de una manera bastante clara la complicidad que privaba entre un sector importante de la prensa y el poder en aquellos momentos. En dicho documen- 


\section{SECUENCIA}

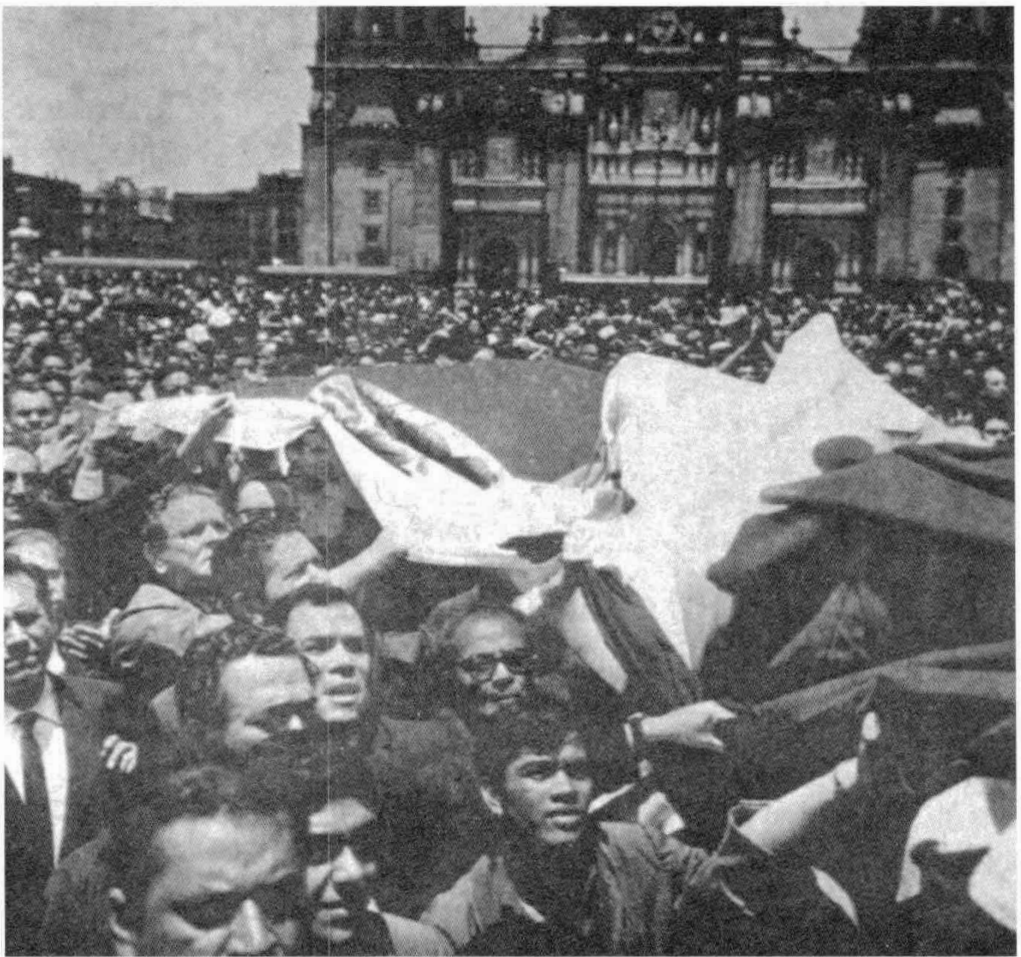

Imagen 2. "En un acto de desagravio al símbolo de la patria, miles de mexicanos se reunieron ayer en la Plaza de la Constitución para bajar la bandera rojinegra e izar en su lugar el pendón nacional. Las aclamaciones a la bandera nacional y las expresiones de "Viva México' atronaban el espacio cuando el lábaro patrio era izado en el astabandera del Zócalo", El Heraldo de México, 29 de agosto de 1968, en Archivo Histórico de la UNAM-CESU.

to, Alarcón agradece a la primera autoridad del país y le informa de sus contactos con Luis Echeverría, secretario de Gobernación, con Emilio Martínez Manatou, procurador de Justicia, con Alfonso Corona del Rosal, regente de la ciudad, y con Marcelino García Barragán, secretario de la Defensa. Le explica que ha recibido de todos ellos la orientación precisa para publicar algunas notas "convenientes" para aislar y condenar a los "agitadores" y para censurar los desplegados "antipatrióticos" de otros medios de comunicación menos dóciles que el propio, como eran los casos de los diarios El Día y el Excélsior. Una parte muy importante de esta subor- 
dinación a los intereses gubernamentales se refería al uso y a la manipulación de las imágenes fotográficas. Al respecto cabe resaltar las tres menciones puntuales sobre este tema que se deslizan en la carta-informe de Alarcón a Díaz Ordaz:

Licenciado y general Corona del Rosal. Al igual que los funcionarios antes señalados, nos ha orientado sobre la forma en que nuestras informaciones resultan negativas a los agitadores, destacando hechos como la agresión a las fuerzas del orden y la profanación a nuestra bandera nacional. Cabe aclarar que nosotros proporcionamos a otros diarios la foto del trapo que izaron en el astabandera los estudiantes [...] Doctor Emilio Martínez Manatou. El jueves pasado me llamó a primera hora para felicitarnos por la forma en que se destacaba en primera plana la foto del Che y las aulas universitarias con nombres de líderes comunistas así como nuestra otra información gráfica [...] Por último, en una reciente entrevista con el licenciado Agustín Salvat, los dos revisamos todas nuestras publicaciones de los acontecimientos, las gráficas y los editoriales de El Heraldo y estuvo de acuerdo en que no se encontraba nada que pudiera interpretarse como negativo al gobierno y que, por el contrario, nuestra política era francamente favorable y de apoyo al régimen. ${ }^{21}$

En pocos documentos puede observarse de una manera nítida el tipo de relación prevaleciente entre la prensa y el ejecutivo, así como las reglas culturales

${ }^{21}$ Carta de Gabriel Alarcón, director del periódico El Heraldo de México, al presidente de la república Gustavo Díaz Ordaz [documento fechado el 24 de septiembre de 1968], citada en la revista Nexos, núm. 246 , junio de 1998, pp. 37-38. Las cursivas son mías. implícitas que moldeaban dicha relación. El director del diario de marras consideraba como algo natural la alineación de su periódico con la versión gubernamental y dentro de esa lógica se concebía "como un soldado más" a las órdenes del presidente. El objetivo central era entonces cuestionar y atacar a los líderes estudiantiles convertidos bajo esta lógica en "agitadores" y defender y reivindicar las certezas oficiales. En esta lucha ideológica, la utilización editorial de las fotografías desempeñaba un papel estratégico en la defensa del orden y el posible impacto en la opinión pública. En este contexto, la publicación de la fotografía de los carteles con la figura del Che en las aulas universitarias resultaba muy importante para documentar la injerencia extranjera en el conflicto, y la construcción del episodio del agravio a la bandera representó otro momento estratégico clave, que marcó el inicio de una nueva etapa de desprestigio de los medios hacia el movimiento estudiantil y definió la organización de una campaña gubernamental mucho más agresiva, que buscó el aniquilamiento de las fuerzas estudiantiles por todos los medios.

Conviene, por lo tanto, que retrocedamos un poco para revisar el contenido gráfico de esta política editorial desde una perspectiva más amplia.

\section{La ambivalencia de agosto}

A principios de agosto la estrategia del diario contemplaba dos aspectos: por un lado, se trataba de responsabilizar al Partido Comunista de la violencia y del caos desatados. Cinco fotografías en primera plana documentaban la captura de miembros prominentes de ese partido: Gilberto 
Rincón Gallardo, Mario H. Hernández, Salvador Sainz, Fernando Granados y Adolfo García. Todos son presentados como "peligrosos agitadores". En el estilo informativo de la época, la investigación periodística es sustituida por la reproducción de un boletín de la Procuraduría General de la República, el cual señala la existencia de una supuesta reunión el 26 de julio en las oficinas del partido entre los líderes antes mencionados y los representantes de la Central Nacional de Estudiantes Democráticos para enviar grupos de choque al acto organizado por los estudiantes del Politécnico y provocar disturbios. Por otro lado, se defendía la figura democrática del rector Barros Sierra y a los "auténticos" estudiantes, que no tenían nada que ver con la violencia, y que todavía eran considerados como víctimas de los agitadores profesionales.

Una gran foto de primera plana con la figura del rector frente a una explanada pletórica de estudiantes reafirma el mensaje. Sin embargo, la fotografía clave, que muestra la postura del periódico, es la que se refiere a un grupo de estudiantes, que simplemente "colocan" sus carteles en los muros de la Preparatoria núm. 3 (véase imagen 3). No se dice nada respecto al contenido de los mismos, ni de las típicas referencias "altisonantes" dirigidas a las autoridades o al odiado cuerpo de granaderos. Todavía se mantiene la posibilidad de mantener un espacio de civilidad para referirse al movimiento. Una segunda fotografía publicada al día siguiente confirma la estrategia del periódico de rescatar la figura de los "auténticos" universitarios. Para tal efecto, se puede observar en la imagen a un joven con un cartel que reza: "La razón y la ley: las armas universitarias" (véase imagen 4).
Como colofón de esta idea, una fotografía muestra a un grupo de estudiantes de medicina vestidos con el tradicional pantalón y con la bata blanca, que simbólicamente abanderan y protegen de posibles agitadores la marcha encabezada por el rector. Un halo higiénico de pureza podía construírse todavía en torno al movimiento (véase imagen 5). Los reporteros alaban en consecuencia el comportamiento ordenado de los 80000 universitarios que acompañaron al rector, y describen y retratan el apoyo de la gente que aplaudía desde calles y balcones el paso de los jóvenes. Una buena parte de todo esto se recrea en imágenes bajo el concepto unificador del reportaje gráfico.

El arreglo y la negociación no se produjeron en un par de días, como una parte de la opinión pública hubiese esperado. $\mathrm{La}$ intervención del rector no institucionalizó el movimiento, sino que, por el contrario, le dio la legalidad y la autoridad moral necesaria para adquirir una mayor fuerza y para expandirse en todo el país. Las marchas posteriores ya no se circunscribieron a los territorios de la UNAM en el sur de la ciudad, apuntaron a la toma simbólica de un espacio sacralizado por las autoridades revolucionarias: el Zócalo capitalino. En los siguientes días ocurrieron una serie vertiginosa de hechos cruciales: el día 2 de agosto se publicó por primera vez por parte del CNH el pliego petitorio con seis puntos básicos que se convertirían en la razón de ser del movimiento: libertad a los presos políticos, destitución de los jefes policíacos, desaparición del cuerpo de granaderos, derogación del delito de disolución social, indemnización a los familiares de los estudiantes muertos y heridos, y deslinde de responsabilidades de los actos de represión. La orientación 


\section{SECUENCIA}

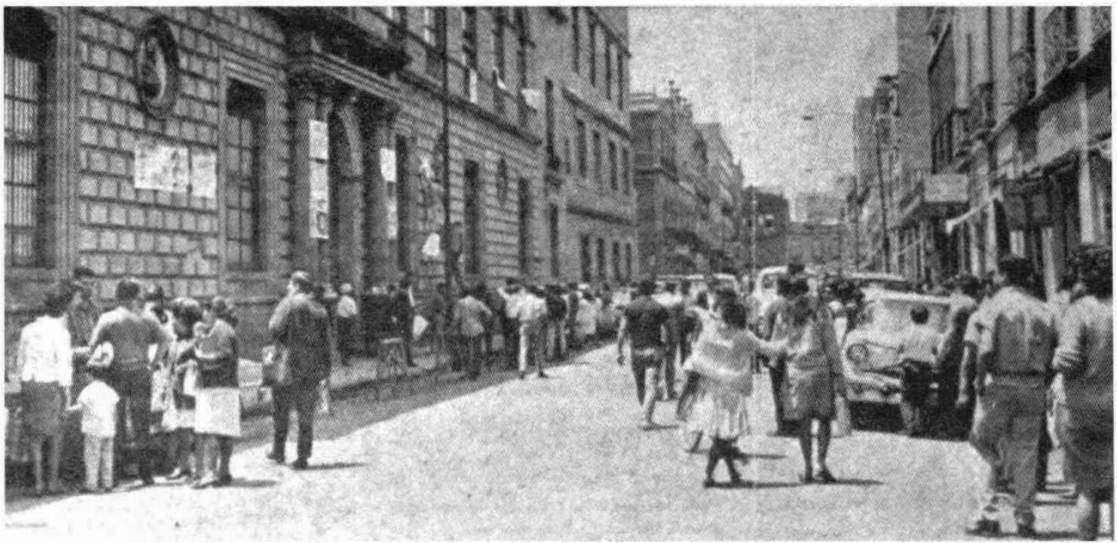

Imagen 3. "En Moneda y Academia, los muros del edificio de la Preparatoria núm. 3 sirvieron para colocar algunos carteles de protesta de los estudiantes", El Heraldo de México, 1 de agosto de 1968, en Archivo Histórico de la UNAM-CESU.

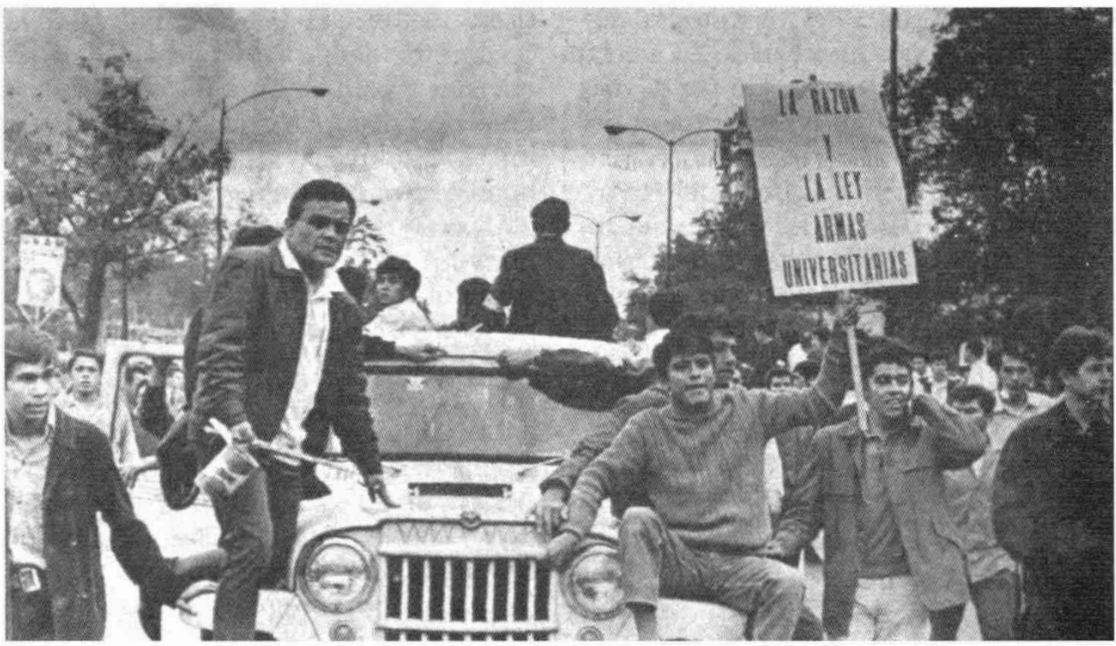

Imagen 4. "Carteles como éste, unidos a las voces de protesta de los universitarios, atrajeron la atención del pueblo que los vio desfilar durante más de tres horas por diferentes arterias", El Heraldo de México, 2 de agosto de 1968, en Archivo Histórico de la unAM-CESU. 


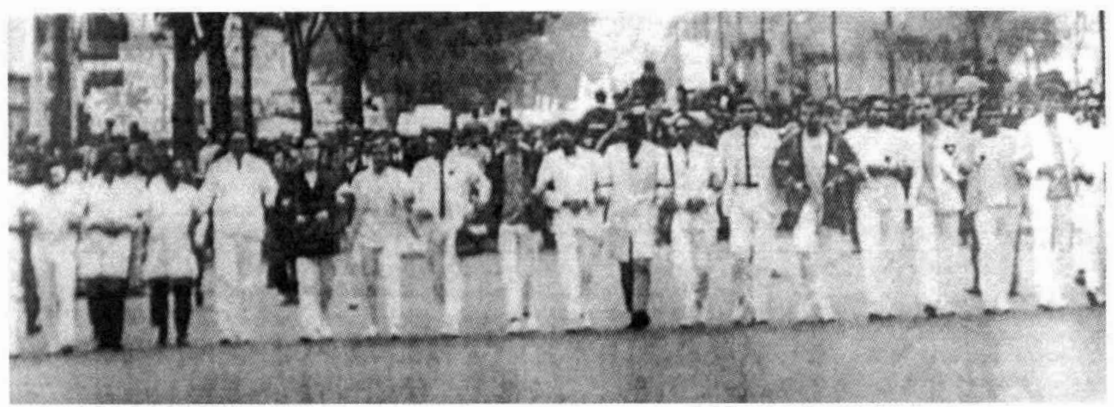

Imagen 5. "Los futuros médicos fueron los encargados de cerrar la enorme columna que ayer desfiló por la avenida Insurgentes, Félix Cuevas, avenida Coyoacán y la avenida Universidad”, en El Heraldo de México, 2 de agosto de 1968, Archivo Histórico de la UNAM-CESU.

concreta de estas demandas permitió la convergencia de miles de estudiantes con tendencias políticas diversas. ${ }^{22}$ El día 5 de agosto se produjo una manifestación de 100000 estudiantes del Instituto Politécnico Nacional que marchan de Zacatenco al Casco de Santo Tomás. Un par de días después, el 8, se publican las primeras declaraciones públicas de una autoridad importante, Alfonso Corona del Rosal, regente de la ciudad de México, en las cuales señala que los hechos estudiantiles eran parte de una conjura para lesionar los intereses de México. ${ }^{23}$

${ }^{22}$ Éste es otro de los puntos que ha logrado consenso a lo largo de estos años. El carácter pragmático del pliego petitorio formó parte de una estrategia cuidadosamente preparada por los dirigentes del CNH para buscar la convergencia de las diferentes tendencias. Fue también el resultado de la composición entre las distintas fuerzas políticas en el interior del Consejo, en la cual las organizaciones tradicionales de izquierda fueron rebasadas desde un principio.

${ }^{23}$ El Heraldo de México, 8 de agosto de 1968.
El crecimiento del movimiento estudiantil marcó también el incremento de los esfuerzos oficiales para contenerlo y controlarlo. Con distintos grados y matices, una buena parte de la prensa de la época cerró filas para defender las verdades oficiales y para atacar a los estudiantes. En el caso de El Heraldo, la ambivalencia inicial se diluyó en un perfil mucho más homogéneo. La estrategia gráfica se acopló, por lo general, a los intereses del diario, y los pies de foto constituyen el instrumento más idóneo para clarificar la perspectiva del editor. El tratamiento visual privilegió el concepto del reportaje colectivo, en el cual las fotografías concretas adquieren un sentido en función de una trama general, compuesta en ocasiones por 30 imágenes, con coberturas de un amplio equipo de fotorreporteros con oficio, que frecuentemente rebasan las imágenes de registro de los hechos principales para captar otro tipo de escenas, que hoy denominaríamos de "vida cotidiana". No obstante, el mayor control del trabajo gráfico se refleja no tanto en 
las composiciones y encuadres de los profesionales de la lente, sino más bien en la uniformidad con que los citados pies de foto cuestionan y defenestran a los estudiantes. En nuestro análisis delinearemos estas coordenadas estructurales, aunque también destacaremos algunas otras que tienen que ver con otro tipo de registros paralelos, menos sujetos a la propaganda del control oficial y a los deseos gubernamentales.

El 13 de agosto tuvo lugar la primera de tres grandes manifestaciones estudiantiles que desembocaron en el Zócalo capitalino, la cual representó una evidente demostración de fuerza y organización del $\mathrm{CNH}$, que exigía respuesta a su pliego petitorio. La nueva relación de fuerzas favorables al organismo estudiantil fue tomada en cuenta por la mayoría de la prensa capitalina, que intentó contrarrestar las iniciativas estudiantiles con una campaña de desprestigio que comienza a ser evidente al día siguiente de la manifestación. La estrategia gráfica de El Heraldo utiliza un reportaje de once imágenes, el cual se centra en los carteles, que ahora son releídos e interpretados como diatribas insultantes contra la autoridad. La foto clave de este desplazamiento fue publicada en la primera plana y corresponde a la figura del comandante Ernesto Che Guevara, muerto apenas un año antes en Bolivia y convertido en icono de la protesta política por los distintos movimientos sociales ocurridos en distintos lugares del planeta en los meses previos. El acento del periódico está puesto en mostrar la presencia de ideas y doctrinas "exóticas" a la idiosincrasia del pueblo mexicano, un reiterado argumento, esgrimido tanto por las autoridades como por diversos grupos empresariales. A diferencia de las imágenes de principios de agosto, que mostraban un orden impecable en las filas de los estudiantes, en esta ocasión el mensaje visual del diario es muy claro y apunta a proyectar una sensación de caos y de desorden (véase imagen 6).

La estrategia gráfica de descalificación hacia los estudiantes continuó con el episodio, ya comentado, del agravio a la bandera. No obstante, conviene señalar que aun en esta coyuntura de desprestigio y satanización se mantuvo a nivel fotoperiodístico un mirador interesado por diversos aspectos que contemplaban una lectura de los distintos sectores sociales. En este caso, dicha perspectiva está representada por tres imágenes. La primera muestra a un par de niñas jugando en la banqueta en un primer plano, mientras al fondo puede observarse un tanque repleto de soldados expectantes, los cuales hacen guardia en las afueras de la embajada de Estados Unidos, en la colonia Cuauhtémoc (véase imagen 7). En la segunda puede verse en un primer plano a cuatro mujeres jóvenes de espaldas, vestidas de falda y tacones que cruzan la calle hacia el Zócalo, mientras al fondo se observa una parte de un contingente de soldados en formación militar. Por una vez el sujeto organizador de la imagen está materializado en este universo femenino, el cual representa a un sector de la población civil que se dispone a entrar en un espacio simbólico de enorme importancia, ocupado por las fuerzas militares. La ausencia de pies de foto permite un margen de lectura más flexible para el posible lector (véase imagen 8).

Una tercera imagen apuntala esta línea intermedia del diario, que no denigra al movimiento y que abre espacios para otro tipo de reflexión. En este caso puede 


\section{SECUENCIA}

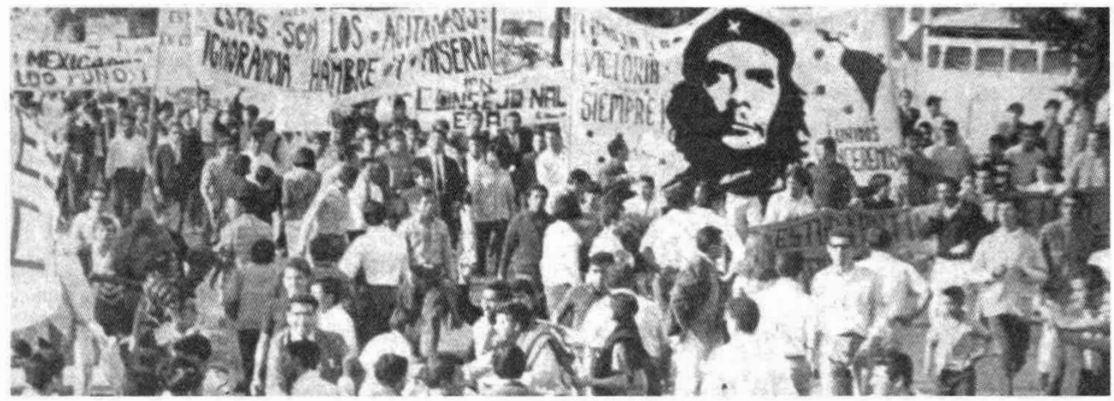

Imagen 6. "Retratos del Che Guevara y pancartas con frases que eran una exaltación abierta y aceptación del régimen comunista de Cuba y otras doctrinas exóticas para nuestro pueblo fueron las banderas de los manifestantes ayer. Impunemente gritaron insultos contra las autoridades y frases ofensivas para las fuerzas armadas y las corporaciones policiacas", El Heraldo de México, 14 de agosto de 1968, en Archivo Histórico de la UNAM-CESU.

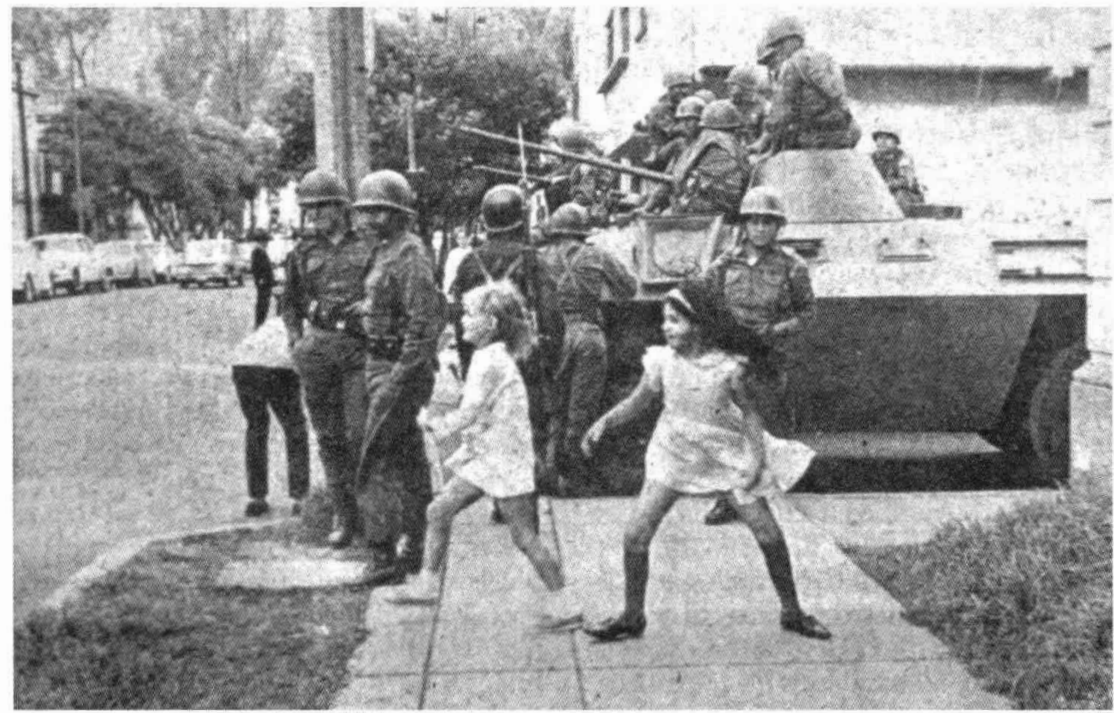

Imagen 7. "Ajenas a los acontecimientos, dos pequeñas cruzan junto a los vehículos blindados apostados junto a la embajada norteamericana”, El Heraldo de México, 28 de agosto de 1968, en Archivo Histórico de la UNAM-CESU. 


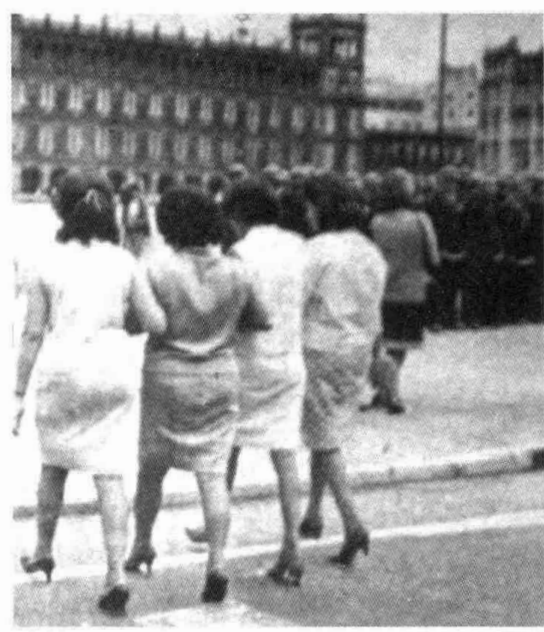

Imagen 8. Sin pie de foto, El Heraldo de México, 31 de agosto de 1968, en Archivo Histórico de la UNAM-CESU.

verse a un solitario soldado frente a una multitud que lo observa desde un puente. $\mathrm{Al}$ fondo se observa el edificio Chihuahua. El militar no apunta con su rifle hacia la gente; por el contrario, sujeta el arma por la parte central en forma displicente. No sabemos si está asombrado, molesto o indiferente frente a los numerosos rostros juveniles que lo observan con atención y desparpajo, pero en perfecto orden. La ausencia del pie de foto impide reorganizar una lectura de la imagen y, aunque el contenido general de las notas es adverso al movimiento, se mantiene aquí la posibilidad de otro tipo de lecturas, en las cuales la evidente soledad del poder represivo frente a la organización de la población civil está presente como una de las lógicas posibles de recepción (véase imagen 9).

\section{Ajustes en la estrategia}

El 1 de septiembre tuvo lugar la ceremonia pública del informe de gobierno de Díaz Ordaz, una fecha simbólica del calendario político mexicano, centrada en aquella época en la exaltación y la apoteosis de la figura presidencial por encima de cualquier otro poder político.

Los reportajes fotográficos consagrados a la fiesta del ejecutivo confirman esta lectura. Por oposición, reinará el silencio y la ausencia de referencias visuales de los estudiantes en las siguientes dos semanas hasta que las tomas violentas de Ciudad Universitaria (CU) y, sobre todo, del Politécnico Nacional definan la estrategia final de confrontación llevada a cabo por las autoridades. En este lapso, Díaz Ordaz aparece retratado en la primera plana, realizando diversas tareas trascendentales para el devenir de la nación, sin contrapesos visuales, molestos o inoportunos. De esta manera, el ejecutivo departe con los gobernadores de los estados en el Club Deportivo Italiano, entrega las instalaciones deportivas a las autoridades olímpicas o posa solemne con los niños más estudiosos de las escuelas primarias de los estados de Puebla e Hidalgo en Palacio Nacional. ${ }^{24}$

En medio de esta indiferencia a los asuntos de los universitarios, un súbito y aislado reportaje gráfico aparece el día 9

${ }^{24}$ El día 6 de septiembre se difunden unas declaraciones del ex presidente Miguel Alemán que responden al esquema cultural de la guerra fría, alimentan la teoría de la conjura y anuncian una posible represión: "Si quienes deseamos prevalezca la paz social de México no damos la batalla frente al virus rojillo incrustado en nuestra sociedad, después habremos de lamentar las consecuencias", El Heraldo de México, 6 de septiembre de 1968, 1a. plana. 


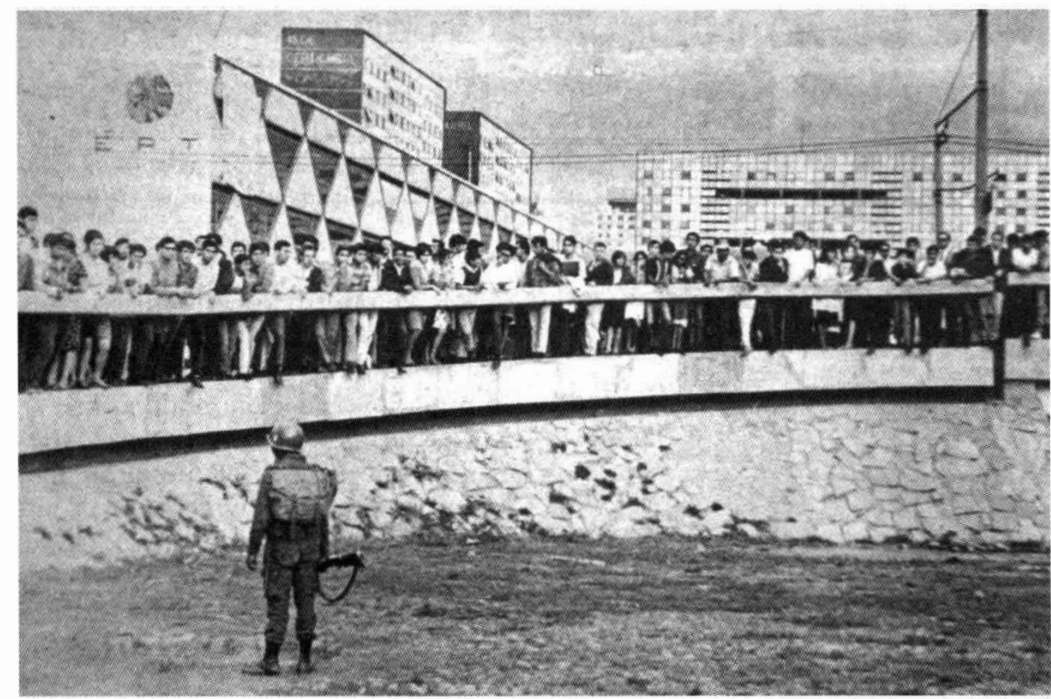

Imagen 9. Sin pie de foto, El Heraldo de México, 31 de agosto de 1968, en Archivo Histórico de la UNAM-CESU.

de septiembre como un rayo en el horizonte seguido por la oscuridad y la ausencia de imágenes en los días posteriores. Se trata de un mitin político de 12000 personas celebrado en la Plaza de Toros México convocado por diversas organizaciones anticomunistas, entre las que destacaban la Organización para la Defensa de los Valores Nacionales y el Movimiento Universitario de Renovación (MURO). La fotografía clave del evento nos muestra a varios de los organizadores que dan la vuelta al ruedo con una efigie que representaba a Ernesto Che Guevara, ratificado de esta manera también como icono de la protesta antiestudiantil. Después de dar un par de vueltas al ruedo, le prenden fuego al monigote, mientras Alfonso Aguerrebere, líder del Muro, animaba el espectáculo parodiando a los grupos de izquierda y se dirigía a la multitud con la consigna: "Queremos uno, dos, tres Ches muertos." Entre las distintas mantas enarboladas por el público destaca una que reivindica los conceptos con los que se identifican los manifestantes: "Dios, patria, familia y libertad". Fiesta brava taurina y religiosidad popular proporcionan el contexto de tono hispanista en el cual se desarrolló este ajuste de cuentas simbólico de un sector de la derecha mexicana. Llama la atención que el emblema escogido por estos grupos para denigrar al movimiento sea el mismo que circulaba en las calles de la ciudad de México reivindicado por miles de jóvenes con intereses ideológicos opuestos. En esta lucha cultural por la apropiación de los símbo- 
los, la figura del comandante Guevara, convertido en icono indiscutible para los distintos grupos, desempeñó uno de los papeles protagónicos (véase imagen 10).

En los días posteriores a la celebración del mitin taurino ocurrió otro hecho importante. El 13 de septiembre tuvo lugar una gigantesca manifestación, la cual convocó de nueva cuenta a decenas de miles de estudiantes que marcharon del Monumento a la Independencia al Zócalo capitalino, en lo que representó la respuesta simbólica del movimiento al informe de gobierno de Díaz Ordaz. La marcha fue cuidadosamente preparada por el $\mathrm{CNH}$, el cual intentó contrarrestar la propaganda gubernamental con una demostración de fuerza al tomar de nueva cuenta la calle. Miles de jóvenes desfilaron por Paseo de la Reforma con esparadrapos y cintas adhesivas en la boca, en lo que desde entonces se conoció como la manifestación del silencio. A pesar de la relevancia de este acontecimiento, el mismo sólo ameritó ocho fotografías a cargo de Cuautle, Flores y Ávila en la página 12 de la publicación y compartió créditos en el mismo lugar con un reportaje gráfico de Valenzuela sobre la "huella de destrucción" que dejó el ciclón Naomi en el estado de Sinaloa. En el imaginario construido por el periódico convergía la presencia estudiantil en las calles de la ciudad de México con los desastres naturales que azotaban a la nación.

Resulta evidente que, después del episodio del agravio a la bandera que motivó el intercambio epistolar privado entre Alarcón y Díaz Ordaz, la dirección del diario tomó la decisión de otorgarle todo el protagonismo político a la figura presidencial y de mantener la cobertura de los sucesos estudiantiles con un bajo perfil.
La apoteosis de dicho protagonismo tuvo lugar a propósito de los festejos patrióticos de la noche del 15 de septiembre con el tradicional grito de independencia y con la celebración de un impresionante desfile militar al día siguiente. Este último acontecimiento dio lugar a un extenso reportaje fotográfico de 16 imágenes a cargo de Ramón Guzmán y de Gustavo Guardiola. En el mismo, puede verse a Díaz Ordaz recorriendo el Paseo de la Reforma en un carro descubierto y recibiendo los saludos de la gente, lo mismo que distintos contingentes armados que desembocan en el Zócalo. Entre otras cosas, este ejercicio gráfico exhibe el poderío de las fuerzas militares, muestra que la toma de los espacios públicos no era privativa ni exclusiva de los estudiantes y pretende certificar el hecho de que en la competencia por auditorios y multitudes, el presidente y el ejército llevaban la delantera. Como en pocas ocasiones, la ausencia de información gráfica sobre un tema determinado constituye la nota más relevante. En efecto, la celebración de la noche del grito de independencia en Ciudad Universitaria y la ejecución del mismo a cargo del ingeniero Heberto Castillo representó un acto simbólico de crítica al poder oficial que no pasó desapercibido por las autoridades. Sin embargo, ningún periódico capitalino publicó alguna nota al respecto. ${ }^{25}$

${ }^{25}$ En los procesos judiciales llevados a cabo contra los dirigentes del $\mathrm{CNH}$ se utilizó el episodio de la celebración del grito de independencia en CU como una muestra de la conjura y de la intención de derrocar al gobierno. En la fiesta popular desarrollada en la explanada central del territorio universitario, aquella tarde se celebraron matrimonios simbólicos y se extendieron actas con la firma del $\mathrm{CNH}$. El poder judicial y en particular el licenciado Eduardo Ferrer 


\section{SECUENCIA}
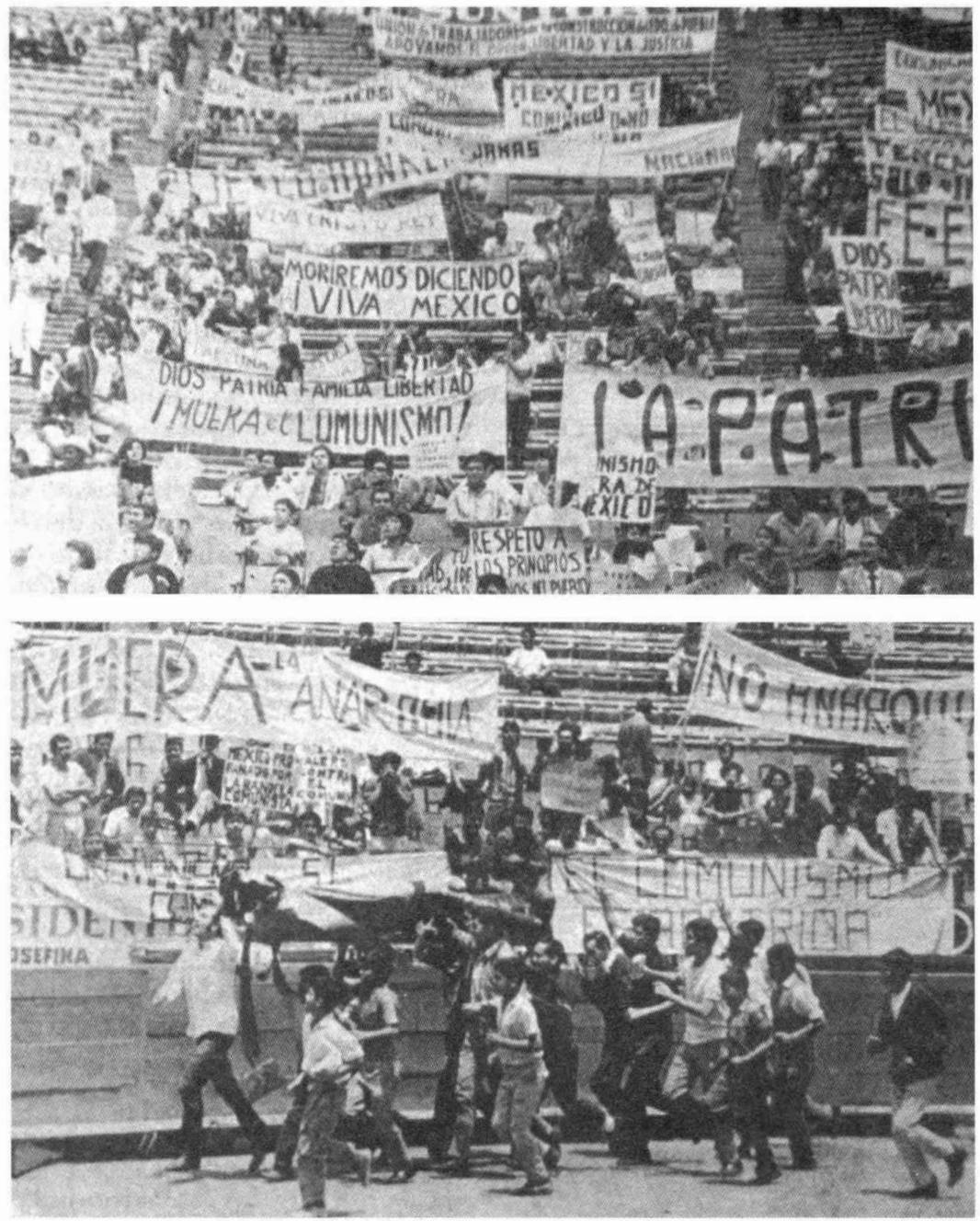

Imagen 10. "Entre el alboroto de un grupo de chiquillos y la algarabía procedente de los tendidos, la caricatura de cartón del Che Guevara dio varias vueltas al ruedo, reabriendo a su paso denuestos e insultos", El Heraldo de México, 9 de septiembre de 1968, en Archivo Histórico de la UNAM-CESU. 
El 19 de septiembre se produjo la toma de Ciudad Universitaria por parte del ejército mexicano, que culminó con cientos de detenidos. La cobertura fotográfica de 18 imágenes a cargo de Quiroz y Valenzuela se centra en la detención de los estudiantes en la Procuraduría del Distrito y omite cualquier imagen de la ocupación militar en territorio universitario. La decisión editorial del diario optó por el registro gráfico de los estudiantes y de los padres de familia deambulando por celdas y pasillos del Ministerio Público y omitió, en cambio, la noticia periodísticamente más atractiva y espectacular, esto es la presencia del ejército en CU. La lógica política se impuso a la modernidad gráfica esgrimida por el propio diario.

\section{Estado de sitio}

La siguiente etapa en la estrategia gráfica del diario se produjo en la última semana de septiembre, cuando la violencia represiva se incrementó en forma cualitativa, y de nueva cuenta aparecieron grandes reportajes gráficos, que evidenciaban la orden de cobertura de los sucesos a varios de los reporteros y fotógrafos más fogueados del diario y, sobre todo, la decisión política de registrar en el campo de los hechos el nuevo tramo del episodio estudiantil, cuyo escenario recurrente fue la unidad habitacional Nonoalco-Tlatelolco, y que representó un salto cualitativo en la violencia desplegada tanto por el ejército como por los distintos cuerpos policiacos

MacGregor, titular del Juzgado Primero de Distrito en el Distrito Federal, utilizó estos documentos como pruebas documentales del complot contra el gobierno. Al respecto, véase Jardí, "Asî", 1988, pp. 145-1.47. legales y clandestinos utilizados en estas operaciones. ${ }^{26}$

El domingo 22 de septiembre el titular de primera plana "Sangrienta refriega en Tlatelolco" inaugura el nuevo giro gráfico del periódico e informa pormenorizadamente acerca de una verdadera batalla campal protagonizada por los granaderos y los estudiantes y colonos de la zona. De acuerdo con los testimonios registrados por los propios reporteros, los primeros arrojaban granadas lacrimógenas a los departamentos, y los universitarios y los tlatelolcas les respondían con piedras y agua hirviendo, lo que constituye uno de los momentos más violentos de aquel otoño. Llama la atención la alianza familiar $\mathrm{y}$ vecinal de los estudiantes con los habitantes de la zona, apenas insinuada por las páginas del diario y la disposición oficial de atacar a estos grupos y sembrar el terror en sus propias casas, a diferencia de la ocupación militar de Ciudad Universitaria en los días previos, que se había caracterizado por una estrategia estrictamente preventiva y un uso más acotado de la violencia.

Un testimonio de cómo se vivieron estos hechos del otro lado, y de los niveles que alcanzó la violencia y la resistencia de colonos y estudiantes puede verse en la siguiente narración de Jaime García Reyes, alumno de la Escuela Superior de Economía en aquellos momentos:

${ }^{26}$ De acuerdo con los hallazgos documentales más recientes en el acervo de la Dirección Federal de Seguridad, se ha podido confirmar la participación a lo largo de todo el episodio estudiantil de agentes policiacos y judiciales adscritos al Departamento del Distrito Federal y a la propia Dirección Federal de Seguridad, a cargo del capitán Fernando Gutiérrez Barrios. 
Así, al llegar el sábado 21 de septiembre supimos que otra vez venían los granaderos. Nos preparamos desde la mañana para enfrentarlos. Considerábamos que la represión no tenía posibilidades si era a través del enfrentamiento. Ese sábado nos dedicamos a preparar un enfrentamiento con los granaderos, a provocarlos para que se acercaran [...] Un espectáculo padrísimo fue ver a los niños de Tlatelolco, con cucharas, escarbando y sacando piedras, porque Tlatelolco estaba empedrado, y subían enormes cantidades de piedras a los edificios. Quemamos trolebuses, quemamos patrullas, quemamos un jeep de Tránsito, interrumpimos el tráfico por San Juan de Letrán [...] La gente de Tlatelolco descubrió que los bóilers automáticos, que en aquella época eran una novedad, permitían tener agua muy caliente. Cuando se acercaban los granaderos, les echábamos baldes de agua caliente. Nosotros utilizábamos las piedras y las bombas molotov, y mientras ellos agotaban sus gases lacrimógenos contra la Vocacional, algunos muchachos les tiraban piedras con hondas. Los granaderos contestaron también con piedras. Los teníamos acorralados. La lucha se extendió hacia Peralvillo, la Exhipódromo y Tepito. En la Exhipódromo de Peralvillo les aventaban llantas encendidas. La lucha, más o menos con ese grado de intensidad, se mantuvo de las siete a las doce de la noche. ${ }^{27}$

El reportaje de cerca de 30 imágenes cuenta con dos fotografías clave, que dan cuenta de hechos desde distintos encuadres y puntos de vista. ${ }^{28} \mathrm{La}$ primera está tomada desde la calle, convertida en los

${ }^{27}$ García, "Batallas", 1988, pp. 84-85.

${ }^{28}$ Nuevamente el diario se lanza a la carga con lo mejor de su repertorio y manda a la zona de combate a los fotógrafos Andrés Manzanares, Ernesto Va- hechos en trinchera urbana. Por un instante se ha roto la seguridad que proporcionaba al profesional de la lente estar del lado del cuerpo represivo y el mismo caos de la contienda obliga al fotógrafo a registrar distintos ángulos de las escenas del combate (véase imagen 11). En la misma tónica, la segunda imagen muestra a un granadero en plena acción, cruzando una calle solitaria mientras apunta con su rifle contra un objetivo situado en la acera de enfrente. Al fondo puede verse la silueta iluminada de la torre Latinoamericana. El pie de foto informa de manera inusualmente precisa que en el número 162 de la calle Santa María la Redonda hubo muchos niños intoxicados a causa de las bombas lacrimógenas disparadas por los soldados (véase imagen 12). Ambas imágenes dan cuenta con oportunidad noticiosa del enorme caos en el que estaba sumida esa zona de la ciudad de México. Se trata de imágenes de guerra que desmentían los comunicados oficiales, que aseguraban mantener el control de la situación. La atmósfera nocturna y una composición fuera de foco contribuyen a recrear la ambigüedad, el caos reinante y la incertidumbre generalizada alrededor de los hechos. ${ }^{29}$

lenzuela, Ismael Casasola, Porfirio Cuautle, Carlos Villagran, Raúl Sosa, Rafael Castellanos, Enrique Flores, Arturo Flota, Guillermo Ávila y José Pereda.

${ }^{29} \mathrm{La}$ cobertura es muy amplia y resulta imposible describirla en el espacio de este artículo. Abarca distintos aspectos de la trifulca, como patrullas y autobuses incendiados, civiles y soldados heridos, familias de la zona contemplando atónitas el espectáculo, una parte de los ventanales del edificio de la Secretaría de Relaciones Exteriores destruido y un departamento de uno de los edificios de la unidad Tlatelolco en llamas. Todas contribuyen a difundir la idea de un escenario caracterizado por una gran violencia y una ausencia de control. 


\section{SECUENCIG}

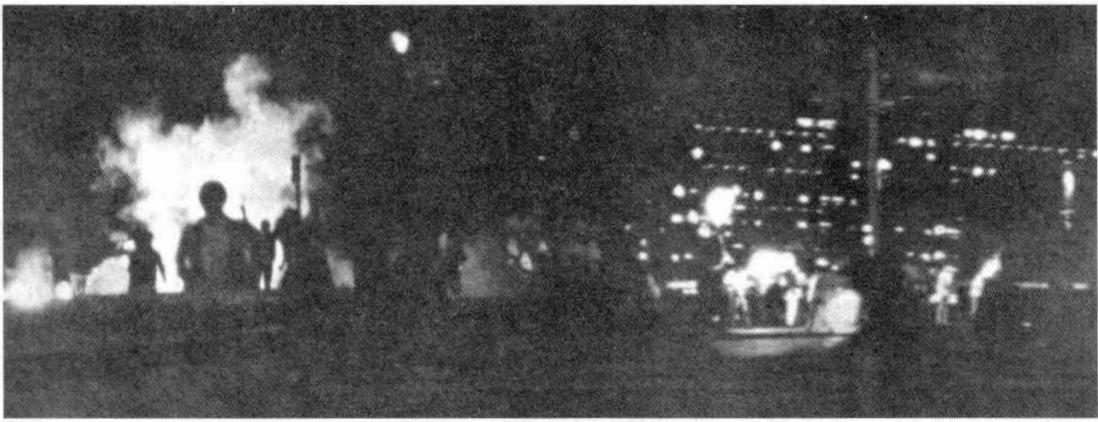

Imagen 11. "Estudiantes y granaderos combaten furiosamente en las calles adyacentes a la unidad Nonoalco-Tlatelolco. Se puede apreciar en la oscuridad los estallidos de las granadas y las bombas molotov", El Heraldo de México, 22 de septiembre de 1968, en Archivo Histórico de la UNAM-CESU.

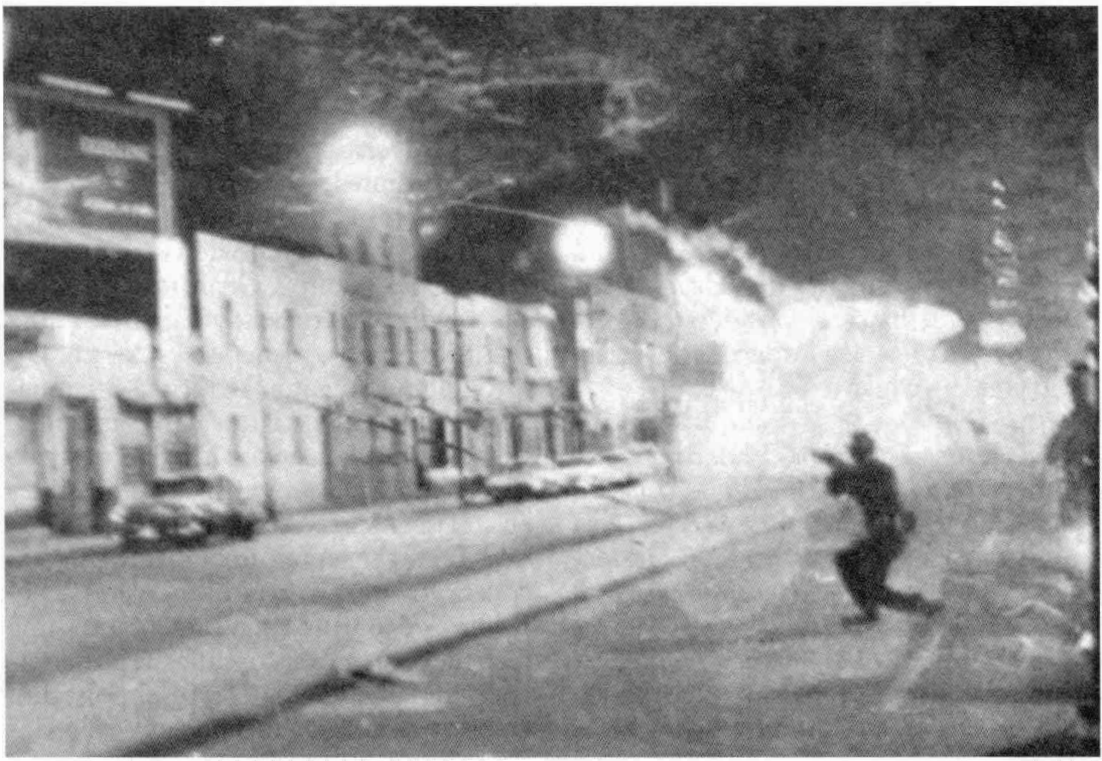

Imagen 12. "En la calle de Santa María la Redonda núm. 162, donde hubo numerosos niños intoxicados por el humo de las granadas", El Heraldo de México, 22 de septiembre de 1968, en Archivo Histórico de la UNAM-CESU. 
Al día siguiente y como parte de los ecos de la trifulca, aparece publicada en la primera plana una fotografía que resume el sentimiento de desolación que privaba en Tlatelolco después de los acontecimientos. La imagen está tomada desde los escombros de uno de los departamentos, semidestruido por los disparos y por las bombas lacrimógenas. La lente del fotógrafo se asoma a través del hueco de la ventana del local, hecha añicos, de la cual sólo se conserva la deteriorada cancelería de metal. La vista da a la conocida Plaza de las Tres Culturas, en la que pueden apreciarse las ruinas prehispánicas, la iglesia colonial $y$, en el fondo, el edificio Chihuahua (véase imagen 13). El pie de foto de la imagen de El Heraldo resulta ambiguo y enfatiza los conceptos de violencia e incomprensión como puntos conceptuales claves para la lectura de la imagen. Se trata de una visión impactante, lograda por el fotógrafo Ernesto Valenzuela, que anuncia, sin saberlo, otra imagen captada por los hermanos Mayo el 3 de octubre desde un departamento del edificio Chihuahua y que ha sido considerada como uno de los iconos de la tragedia de Tlatelolco (véase imagen 14):

En una imagen tomada el 3 de octubre vemos desde muy arriba la plaza de Tlatelolco donde la noche anterior había ocurrido la matanza más grande en la historia del México moderno. Pero en lugar de cuerpos o sangre renemos una reflexión metafórica sobre la historia de la violencia en México. Rodean la plaza las pirámides donde los aztecas ofrecieron su última resistencia a la conquista española; la iglesia colonial, arma del proceso colonizador; los edificios modernos construidos para la clase obrera. Encima de todo y en primer plano están los agujeros en las ventanas hechos por los balazos del ejército, evidencia gráfica de una brutalidad desencadenada por un Estado que rehusó compartir el poder con el pueblo. ${ }^{30}$

Los enfrentamientos entre colonos, estudiantes y granaderos continuaron en todo su apogeo en la zona de Tlatelolco durante los días siguientes y se amplían a otro episodio central del movimiento, que se refiere a la ocupación del Instituto Politécnico por parte del ejército. La preocupación central de la gráfica está concentrada en dar cuenta de los distintos aspectos bélicos del hecho, que queda registrado con el estatus de "batalla campal". A diferencia de la ausencia de registros fotográficos sobre la intervención del ejército en $\mathrm{CU}$, resulta notable el trabajo de los fotorreporteros, que muestran la estrategia militar que incluye la coordinación de diversos grupos policiacos, civiles y paramilitares.

Un nuevo y extenso reportaje gráfico de 30 imágenes a cargo de Guzmán, Flota, Casasola, Quiroz, Guardiola, Castellanos, Ávila, Valenzuela y Cuautle, cubre distintos aspectos del episodio bélico. Los fotógrafos estuvieron siempre posicionados del lado del ejército y desde ahí registraron algunas imágenes importantes, que dan cuenta de los movimientos militares en su fase inicial, cuando rodearon las instalaciones y se enfrascaron en una balacera contra los estudiantes que defendían el recinto. A continuación presentamos una secuencia de tres fotografías representativas de la cobertura total del episodio. La primera muestra una hilera de soldados tendidos en el suelo, en disposición para entrar en combate, justo a la entrada del

${ }^{30}$ Mraz, "Fotografiar", 1997, pp. 116-117. 


\section{SECUENCIG}

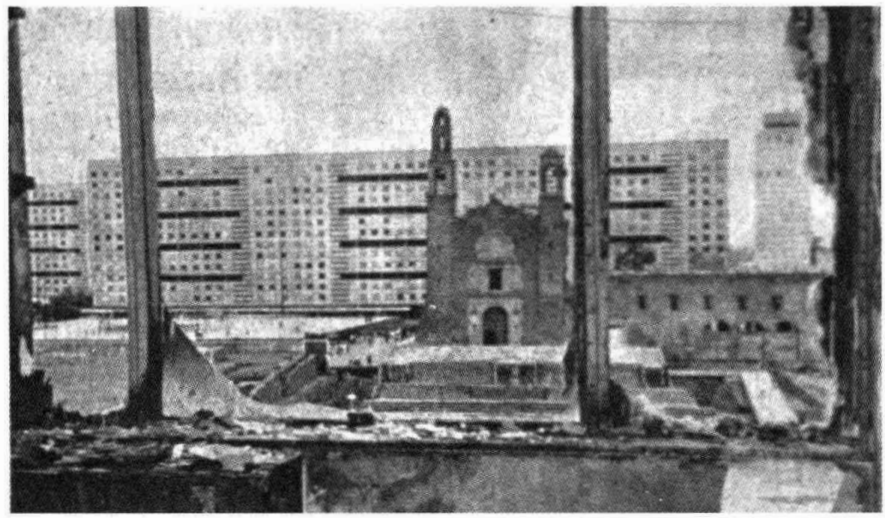

Imagen 13. "Tres culturas, orgullo de México, están amenazadas por la violencia y la incomprensión. Esta gráfica de Ernesto Valenzuela habla por sí sola de lo ocurrido la noche del sábado en Santiago Tlatelolco, donde se conjuga el pasado con el presente de nuestro país", El Heraldo de México, 23 de septiembre de 1968, en Archivo Histórico de la UNAM-CESU.

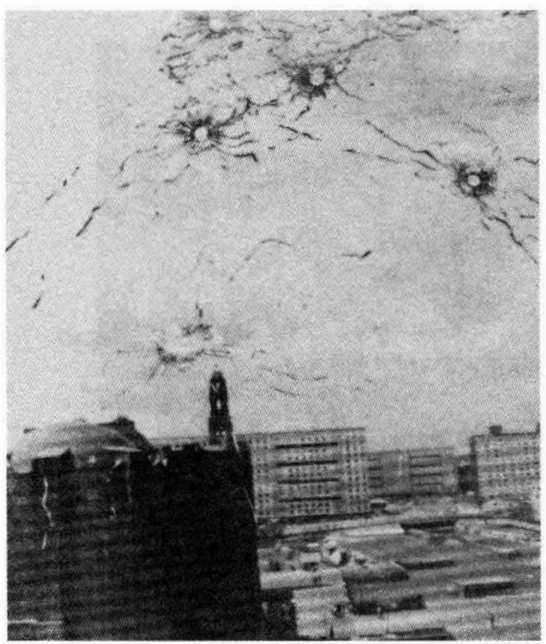

Imagen 14. Sin título, 3 de octubre de 1968, hermanos Mayo, en Archivo General de la Nación.
Politécnico (véase imagen 15). En la segunda puede observarse a otro grupo de soldados parapetados tras una barricada compuesta por los pupitres de las aulas politécnicas (véase imagen 16). El pie de foto denuncia el gasto inútil del Estado en "aulas cómodas" convertidas en escombros. La imagen retoma la lectura inducida y plantea en forma desconcertante el nuevo uso de los pupitres universitarios a cargo de las fuerzas militares. Finalmente, la tercera fotografía retrata a un grupo de agentes armados con pistolas y soldados con rifles, ambos apostados en el suelo en posición de combate, protegidos por dos camiones del transporte público (véase imagen 17).

Esta última fotografía capta muy de cerca a estos personajes, cuyos rostros aparecen de una manera nítida. Constituye el primer registro del diario en el que 


\section{SECUENCIA}

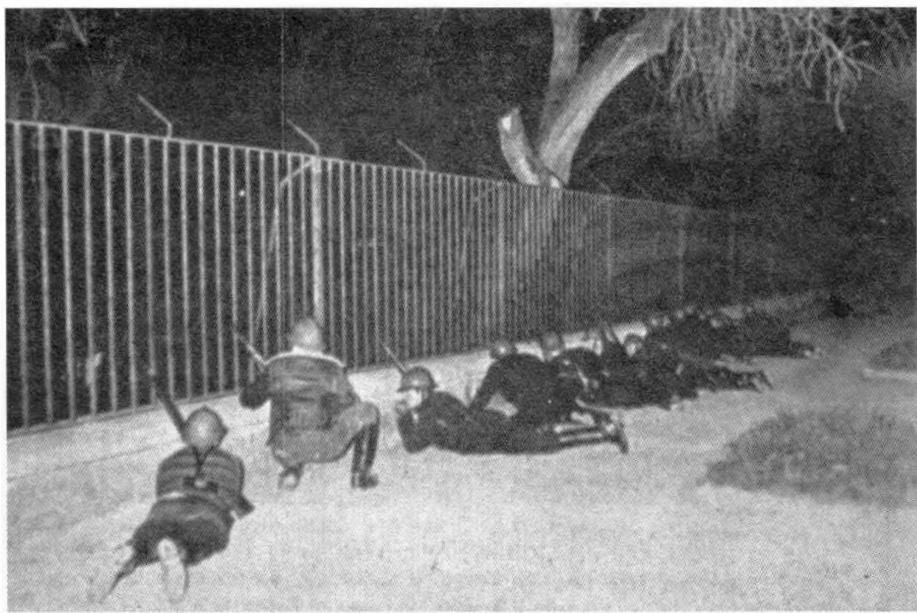

Imagen 15. "He aquí otro aspecto de la batalla que se escenificó anoche en el Casco de Santo Tomás", El Heraldo de México, 24 de septiembre de 1968, en Archivo Histórico de la UNAM-CESU.

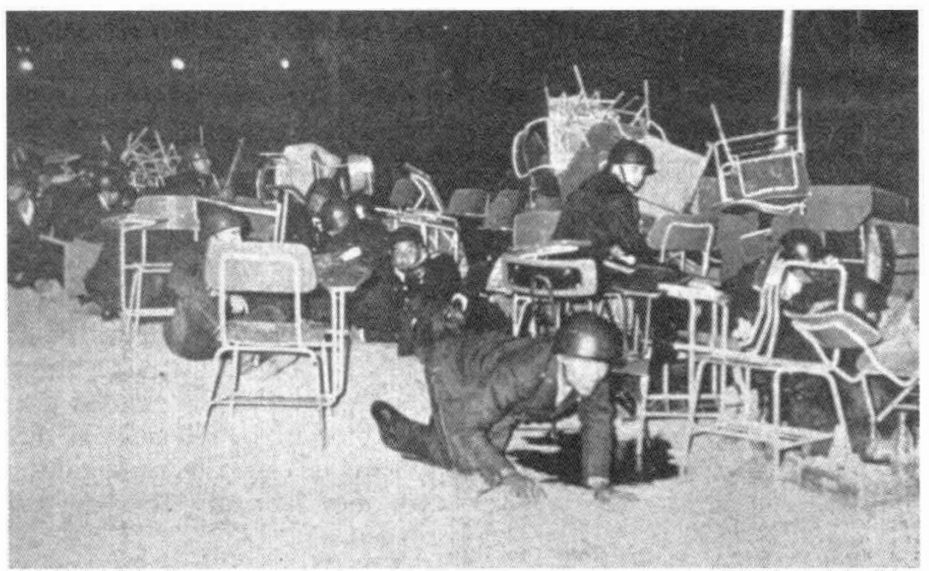

Imagen 16. "Los miles de pesos gastados en proporcionar aulas cómodas fueron convertidos en hacinamiento de escombros y barricadas", El Heraldo de México, 25 de septiembre de 1968, en Archivo Histórico de la UNAM-CESU. 


\section{SECUENCIA}

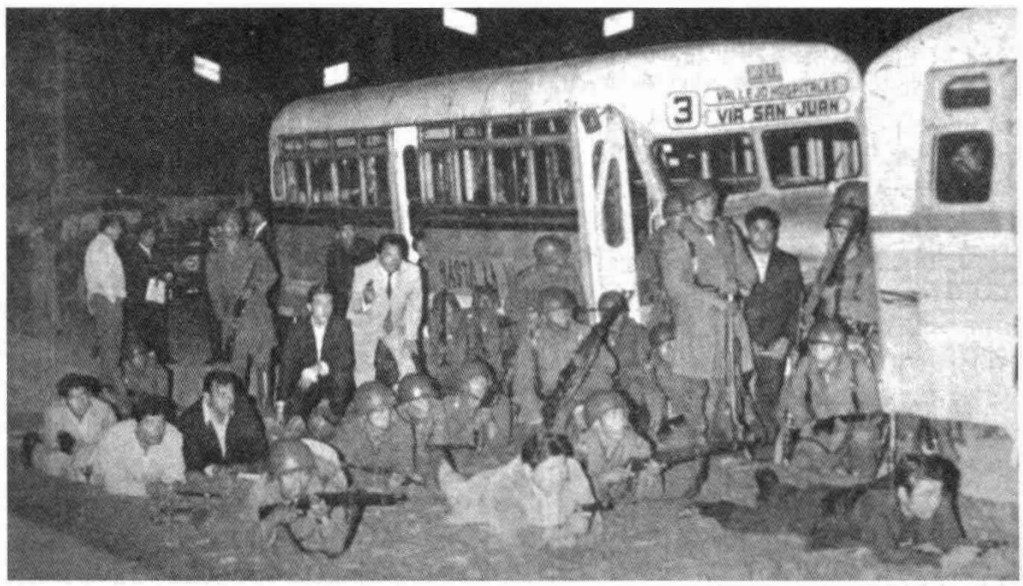

Imagen 17. "Miembros del ejército y de la policía metropolitana, parapetados en uno de los autobuses del servicio urbano y tirados en el suelo otros, repelen la agresión. La escena corresponde a la madrugada de ayer", El Heraldo de México, 25 de septiembre de 1968, en Archivo Histórico de la UNAM-CESU.

puede verse en una acción coordinada con el ejército a miembros del batallón Olimpia, con el famoso pañuelo blanco en la mano. Evidentemente, los pies de foto omiten cualquier información al respecto $y$, por el contrario, enfatizan el hecho de que tanto civiles como militares respondieron a la agresión que provenía del bando estudiantil. A escasos diez días de la tragedia del 2 de octubre, aparece aquí por primera vez la evidencia gráfica publicada en este diario que muestra no sólo la participación de los integrantes del Olimpia en la represión, sino su colaboración estrecha con la policía y el ejército. ${ }^{31}$

${ }^{31}$ A partir de la apertura de los archivos de la Dirección Federal de Seguridad ya mencionada, sabemos que durante estos hechos intervinieron no solamente agentes de esta institución, sino de otras dependen-

\section{La matanza del 2 de octubre}

El segundo episodio gráfico de esta etapa caracterizada por el incremento de la violencia está representado por la cobertura de los trágicos acontecimientos del 2 de octubre. El registro de la devolución de las instalaciones de la UNAM y la evacuación de las tropas de la misma apenas si ameritó algunas fotos aisladas. El día 2 apareció publicado en primera plana la fotografía de unos atletas olímpicos de nacionalidad inglesa realizando su entre-

cias, tales como el Departamento del Distrito Federal, a cargo del general Alfonso Corona del Rosal. La señal distintiva de los diversos grupos consistía en el uso del guante blanco. De tal manera que los personajes de la fotografía podrían pertenecer a cualquiera de estas agrupaciones. 
namiento en la explanada central de Ciudad Universitaria, con la Biblioteca Central y el famoso mural de O'Gorman como telón de fondo (véase imagen 18). Esta curiosa imagen transmitía al lector la sensación de una vuelta a la normalidad en la vida cotidiana del campus universitario. El mensaje gráfico y editorial buscaba difundir la idea de que el movimiento estudiantil había declinado por completo con la ocupación militar y la posterior devolución de las instalaciones a las autoridades, hasta el grado de no tener presencia alguna en el propio campus. El diario proyecta de esta manera la idea conservadora de la neutralidad olímpica del atletismo para contraponerla a la politización defendida por los estudiantes en los meses anteriores.

Otras fotografías mostraban con lujo de detalle la represión policiaca contra los estudiantes, pero estas crudas escenas provenían de la agencia Prensa Unida Internacional (UPI por sus siglas en inglés) y se referían a marchas estudiantiles contra la guerra de Vietnam ocurridas en los lejanos escenarios de Boston y Nueva York. La ilusión de la vuelta a la normalidad continuaría con dos imágenes publicadas el 3 de octubre: la visita de la Doña, María Félix, a la Villa Olímpica acompañada de su esposo, Alex Berger, donde "causó la admiración de los visitantes y turistas que la admiran" y la llegada del cohete espacial Thor-Agena, de 25 metros de longitud de Cabo Kennedy a Ciudad Universitaria para una exposición sobre La Conquista del Espacio, junto al Museo de Ciencias, que congregó a una pequeña multitud en el seno mismo de la explanada principal de CU.

El crudo regreso a la realidad no tardó en llegar. Un reportero de la época ha

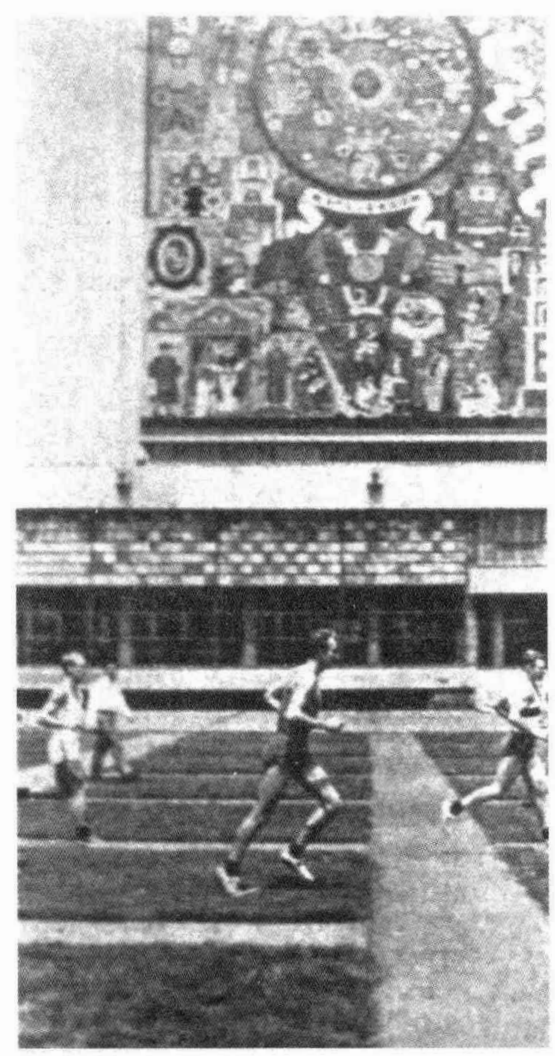

Imagen 18. "Los atletas olímpicos aprovecharon los enormes prados de CU para entrenar. En la foto el equipo británico", El Heraldo de México, 2 de octubre de 1968, Archivo Histórico de la UNAM-CESU.

mencionado que la mañana del 2 de octubre los directores de los principales diarios tuvieron una reunión con Díaz Ordaz y que ahí tuvieron conocimiento de que algo importante iba a ocurrir en Tlate- 
lolco. ${ }^{32}$ El rumor tiene visos de realidad, dado el impresionante despliegue reporteril ordenado por la dirección de los distintos diarios para cubrir un evento aparentemente poco relevante, esto es, un mitin anunciado de apenas 5000 personas, en pleno reflujo del movimiento estudiantil. El Heraldo mandó la tarde del 2 de octubre a varios de sus mejores reporteros y fotógrafos a cubrir la noticia a la Plaza de las Tres Culturas en Tlatelolco. La lista de los periodistas posicionados en distintos lugares de la plaza estuvo integrada por los reporteros Miguel Reyes Razo, José Falconi, Rodolfo Rivera, Roberto Legorreta, Ramón H. Cossío, Joaquín López Dóriga y Manuel Espejel, y los fotógrafos Eduardo Quiroz, Ramón Guzmán, Gustavo Flores, Raúl Sosa, Guillermo Ávila y Rafael Castellanos.

"Sangriento encuentro en Tlatelolco. 26 muertos y 71 heridos": el titular de primera plana, publicado el 3 de octubre, justificaba plenamente la cobertura periodística desplegada. Sin embargo, en lugar de una crónica detallada de los sucesos, lo que predomina es el tono oficial del previsible boletín gubernamental, que justifica la matanza e informa que distintos francotiradores apostados en cuatro edificios de Tlatelolco dispararon contra el ejército con balas expansivas de uso exclusivo del ejército estadunidense en Viet-

\footnotetext{
${ }^{32} \mathrm{El}$ testimonio es de Enrique Metinidez, reportero gráfico de La Prensa y una verdadera institución en el campo de la nota roja periodística en México: "En La Prensa ya se sabía de lo del mitin en Tlatelolco [..] en los periódicos corrió la versión de que el mismo 2 de octubre por la mañana, el presidente se había reunido con los directivos de todos los diarios para informarles de lo que iba a suceder con el movimiento estudiantil." Morales y Ortiz, Enrique, 2000, pp. 31-32.
}

nam y provocaron una batalla campal con el saldo de varios civiles y militares muertos. El diario lamenta incluso el hecho de que algunos corresponsales extranjeros presentes en la plaza informaran a sus países sobre los sucesos, y con esto perjudicaban la imagen olímpica de México en el extranjero:

Minutos después de iniciado el encuentro, los teletipos comenzaron a enviar a todo el mundo cables sobre los sucesos -visiblemente abultados-, causándose un daño irreparable e incalculable para el país. ${ }^{33}$

En lo que toca a la información gráfica, no se publicó ninguna imagen de la represión o de los civiles asesinados por los francotiradores o por el ejército. Como en ningún otro reportaje anterior, la censura delinea y acota los márgenes específicos en que las secuencias tendrán lugar. Las fotografías omiten cualquier escena de carácter represivo.

Las imágenes clave del reportaje son dos. La primera se orienta a mostrar la evidencia de la participación de agitadores profesionales de nacionalidad extran-

\footnotetext{
33 "Sangriento encuentro en Tlatelolco", El Heraldo de México, 3 de octubre de 1968, p. 6A. Otra muestra de la preocupación del diario por la imagen del gobierno en el exterior se mostraba en el hecho de publicar en la misma página en la que se relataba el "sangriento encuentro", la noticia de que al día siguiente llegaría al país el británico Philip Noel, premio Nobel de la Paz 1959, quien tenía una visión muy distinta del país de la de los exagerados corresponsales extranjeros, y que había declarado lo siguiente: "México, país que piensa y actúa con espíritu nuevo y que ha entregado su esfuerzo y cooperación permanente para que todos vivamos en un mundo de paz y donde los hombres convivan dentro de la libertad."
} 
jera en el movimiento. Aparece publicada en la primera plana, junto al titular que anunciaba la cifra de 26 muertos en Tlatelolco, y muestra la presentación de cuatro jóvenes ante las autoridades - un mexicano, un alemán y dos guatemaltecos--, que formaban parte de una peligrosa banda de "agitadores profesionales", la cual había tenido una participación activa en los disturbios estudiantiles de las últimas semanas (véase imagen 19).

La segunda imagen constituye la única fotografía en la que aparece el mitin, y esto, antes de que se iniciara la matanza. La atención del fotógrafo no está puesta en la gente, que ocupa la parte inferior de la imagen y de la cual sólo distinguimos sus cabezas. Todo el peso está puesto en la enorme mole de concreto del edificio Chihuahua, que ocupa la totalidad del cuadro. Al igual que en las notas de los reporteros, la crónica visual sugiere que el punto principal de los hechos estriba en la acción de los francotiradores apostados en los edificios, y no en la acción represiva de las tropas dirigida a una multitud inerme en la plaza (véase imagen 20 ).

En los días posteriores a la matanza, la atención gráfica del diario continuó en el mismo tono y se concentró en varios puntos: mostrar los efectos del caos y la destrucción provocada por los estudiantes a través de las fotografías de los tranvías y camiones incendiados; registrar el éxodo de algunos habitantes de Tlatelolco, que huían masivamente del lugar cargando algunas de sus pertenencias más importantes; y constatar la gran cantidad de jóvenes detenidos en las delegaciones y las largas filas de ciudadanos en las calles, a la espera de reconocer el cadáver del familiar en cuestión. Dichas filas contradecían las declaraciones oficiales en torno al restringido número de muertos y acercaban al lector implícitamente a deducir la magnitud real de los hechos. Una secuencia de tres pequeñas fotografías a cargo de Ramón Guzmán se ocupa de algunos de estos puntos (véase imagen 21).

El último capítulo de esta historia está representado por el episodio organizado por el gobierno para justificar la matanza y desprestigiar al movimiento: la difusión masiva de las declaraciones ministeriales de Sócrates Amado Campos Lemus, uno de los líderes del CNH detenido la tarde del 2 de octubre, quien sostenía que el levantamiento estudiantil había sido parte de una conjura comunista para derrocar al gobierno y boicotear la celebración de las Olimpiadas. En dicha conjura habrían tenido un papel protagónico el catedrático Eli de Gortari; la escritora Elena Garro, ex esposa de Octavio Paz; el ingeniero Heberto Castillo, maestro universitario muy ligado al movimiento; Carlos Madrazo, ex presidente del PRI y Braulio Maldonado, ex gobernador de Baja California. ${ }^{34}$

La fotografía de Campos Lemus demacrado y cabizbajo frente a una multitud de reporteros y fotógrafos constituye un cierre simbólico de la cobertura gráfica de El Heraldo (véase imagen 22). La forma en que la Procuraduría General de la República distribuyó entre los principales diarios una serie de fotocopias con el contenido de las declaraciones del líder estudiantil ante las autoridades del Ministerio Público y el diseño teatral de su presentación como trofeo de caza frente a los medios ratifican a la distancia el autoritarismo del gobierno de Díaz Ordaz y la subordinación total del poder judicial en

${ }^{34}$ El Heraldo de México, 5 de octubre de 1968. 


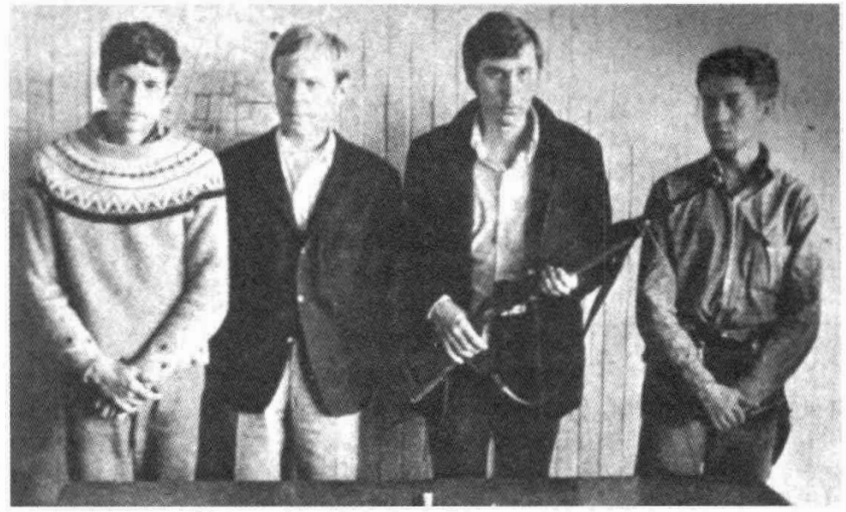

Imagen 19. "Con un fusil automático el mexicano Ernesto Cepeda posa para los fotógrafos en la Jefatura de Policía. A su lado está el aleman Otto Zoller y en los extremos los guatemaltecos Mario René Solórzano y Carlos Rolando Segura Medina. Todos forman parte de un grupo de agitadores profesionales, principalmente extranjeros, que han participado en varios asaltos, atentados y disturbios callejeros", El Heraldo de México, 3 de octubre de 1968, en Archivo Histórico de la UNAM-CESU.

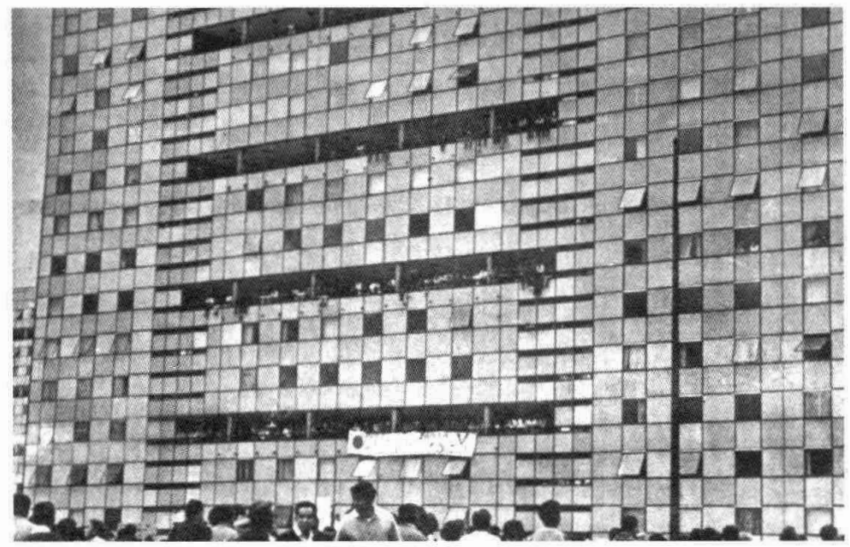

Imagen 20. "Este es el edificio Chihuahua, momentos antes del mitin que el CNH pretendió realizar ayer por la tarde", El Heraldo de México, 3 de octubre de 1968, en Archivo Histórico de la UNAM-CESU. 


\section{SECUENCIA}

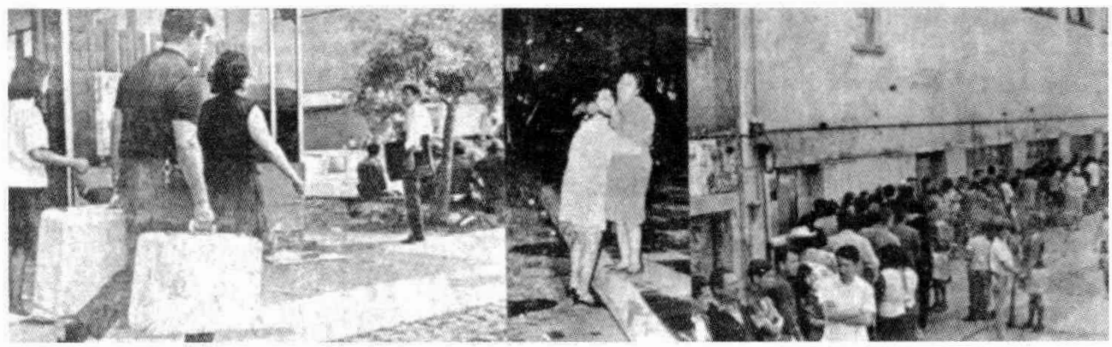

Imagen 21. "Las escenas de estas tres fotografías son en cierta forma la culminación de las horas de violencia que vivió Tlatelolco el miércoles pasado. 1. Ayer cientos de personas salieron de los edificios adyacentes a la Voca 7 en busca de nuevo hogar. 2. La escena se repitió cientos de veces la noche del miércoles. La desesperación, el dolor de perder o ver morir a un ser querido. 3. Y frente a la Tercera Delegación, la interminable fila de quienes buscaban a algún cadáver, sin desear encontrarlo", El Heraldo de México, 4 de octubre de 1968, en Archivo Histórico de la UNAM-CESU.

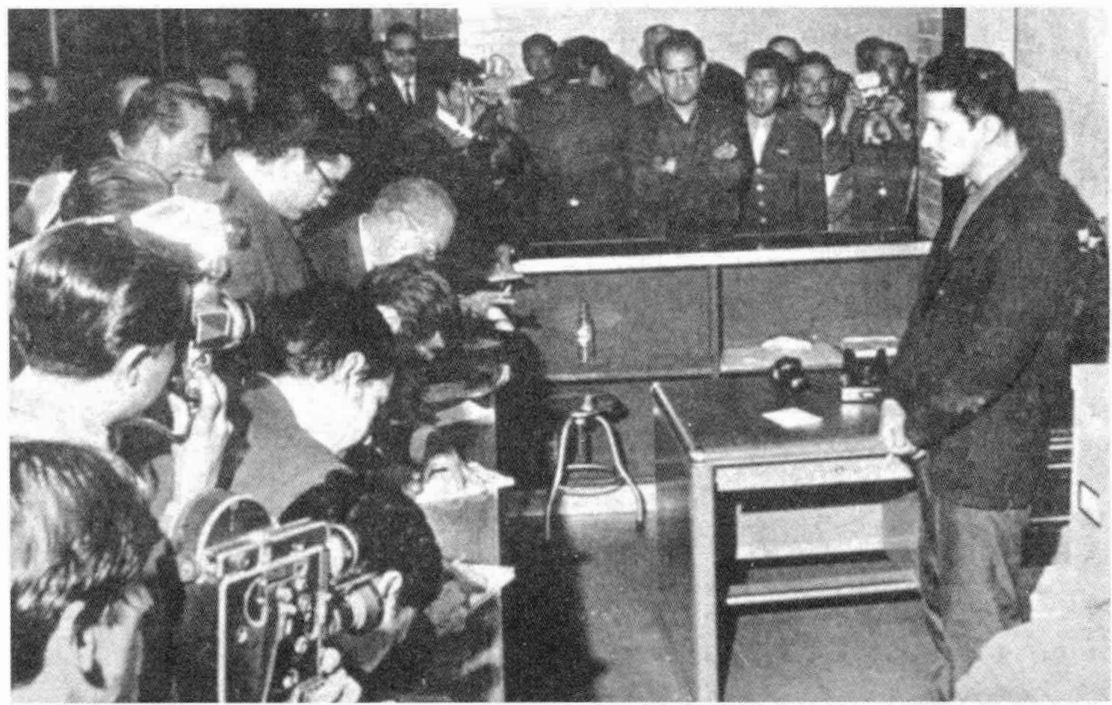

Imagen 22. "Frente a reporteros y fotógrafos, Campos Lemus señaló por vez primera fechas, cifras y toda clase de pormenores. Ahora se sabe que los nombres que corrían en meros rumores podrán pronto confirmarse", El Heraldo de México, 6 de octubre de 1968, en Archivo Histórico de la UNAM-CESU. 
torno a la figura presidencial. El asunto de la supuesta conjura de intelectuales en contra del gobierno no es casual. Muestra con elocuencia la verticalidad del régimen y su enorme desconfianza hacia este grupo. El proceso se había iniciado con las primeras declaraciones públicas del regente de la ciudad en agosto y quedó ratificado con la versión oficial del informe presidencial, que responsabilizaba a los llamados "imodernos filósofos de la destrucción, que están en contra de todo y a favor de nada!", de confundir y manipular a los auténticos estudiantes poniéndolos en contra del gobierno y utilizándolos como carne de cañón de una represión anunciada. ${ }^{35}$

En los días posteriores, la nota roja desplazó a los grandes reportajes gráficos de primera plana que habían caracterizado al movimiento en los meses de agosto y septiembre. En el nuevo orden de cosas, la publicación de las fotografías comenzó a aparecer de manera cada vez más esporádica. La concentración de todos los medios de comunicación en la cobertura de la celebración de los XIX Juegos Olímpicos en la ciudad de México terminó de cerrar la losa. En este contexto, las declaraciones oficiales del CNH decretando la terminación del movimiento el 5 de diciembre no conmovieron a nadie. La represión gubernamental había logrado sus objetivos, no solamente con la eliminación física de cientos de jóvenes, sino con el envilecimiento de la atmósfera pública, la utilización de políticos e intelectuales para denigrar a los líderes estudiantiles, la persecución de los disidentes y, sobre todo, la creación de una atmósfera de temor ge-

${ }^{35}$ Ibid., 2 de septiembre de 1968. neralizado que inhibió las aspiraciones democráticas lúdicas y festivas de las semanas previas al 2 de octubre y convirtió a esta trágica fecha en un punto de convergencia de la impunidad y de las inocuas efemérides oficiales en las décadas posteriores.

\section{CONSIDERACIONES FINALES}

La recuperación institucional del movimiento estudiantil de 1968 comenzó a principios de la década de los setenta. Un halo romántico comenzó a permear las interpretaciones. Los peligrosos "agitadores" y "alborotadores" regresaron poco a poco a su condición de estudiantes. La reforma política de 1978 y el desmoronamiento del autoritarismo presidencial y el monolitismo partidista abrieron las condiciones para nuevos diagnósticos y evaluaciones. En 1986, el surgimiento de un nuevo y poderoso movimiento estudiantil, que desembocó en la creación del Consejo Estudiantil Universitario y la celebración de un congreso universitario, permitieron voltear la vista al 68 y apreciar las rupturas y las continuidades, tanto en el análisis de las organizaciones estudiantiles como en el del sistema político mexicano. Finalmente, la pérdida de la presidencia por parte del PRI en las elecciones del año 2000, la apertura de los archivos secretos de la Dirección Federal de Seguridad y el avance de las investigaciones documentales en todos los campos han permitido reconstruir una imagen cada vez más compleja del movimiento estudiantil.

A 35 años de distancia, los hilos de la discusión apuntan a dos factores: el primero, con una carga política y jurídica, 
se orienta a la necesidad de establecer justicia y de no proteger la impunidad de los responsables de la matanza, y el segundo, con una carga más cultural, apunta a la necesidad historiográfica de que la tragedia del 2 de octubre no desplace otros aspectos centrales del movimiento e impida una evaluaçión del mismo en su totalidad. ${ }^{36}$

Desde el punto de vista de una historia gráfica, y atendiendo a las coordenadas que acotaron la relación entre la prensa y el poder en el periodo estudiado, la aportación de este tipo de estudios puede orientarse a mostrar de qué manera se organizó visualmente esta representación del movimiento estudiantil como parte de la conjura anunciada con anticipación por las autoridades. En esta primera aproximación hemos desarrollado un análisis de las representaciones fotográficas del movimiento a partir del punto de vista de El Heraldo, al mostrar las distintas etapas por las que atravesó la estrategia visual del diario. En todas ellas aparece el ojo censor del Estado como instrumento privilegiado que va marcando las temáticas, las reiteraciones y las omisiones, así como el incremento o el descenso de las imágenes publicadas, de acuerdo con la evaluación política de los acontecimientos.

36 "Todo apunta a la normalización del 68 y su inclusión definitiva entre los legados fundamentales en este siglo. Se apagan susceptibilidades, resentimientos y defensas pasionales. Es irreversible la penalización moral al gobierno diazordacista, al PRI del 68 , a los diputados, senadores, jueces, periodistas venales, etc. Por eso mismo, la venganza carece de todo sentido, pero la sociedad reclama el esclarecimiento de lo sucedido en Tlatelolco, y el examen de cómo fure posible tanto abuso de poder, tanta represión, tanta impunidad." Monsiváis, “68”, 2002, p. 286.
Resulta importante destacar que el análisis de las imágenes fotográficas está condicionado tanto por los pies de foto como por la diagramación editorial y el contenido específico de las notas y los reportajes del propio periódico.

No obstante lo anterior, también es relevante diferenciar entre los intereses y la preocupación central del diario, supeditados a la teoría de la conjura ya mencionada, y la exploración fotográfica de otros aspectos marginales, que ilustran otras áreas de la vida cotidiana de la época, se alejan del horizonte de la mirada de la censura y permiten incluso el cuestionamiento implícito del discurso oficial de las autoridades. Debido a lo anterior, resulta importante señalar la necesidad de recoger los testimonios de los reporteros y fotógrafos que presenciaron los hechos, así como acudir a los acervos de éstos y de los periódicos, y cotejar las imágenes publicadas y las que no lo fueron. Sólo comparando esta crónica visual de $E l$ Heraldo con la de otros periódicos de la época podremos llegar al arribo de conclusiones más sólidas que nos permitan establecer una evaluación objetiva del papel desempeñado por la prensa gráfica durante los acontecimientos de 1968.

Postdata: El Heraldo de México, 3 de octubre de 2003

La tarde del 2 de octubre de 2003 tuvo lugar la marcha ritual para conmemorar la tragedia de la matanza de Tlatelolco. En esta ocasión, la tradicional manifestación se vio opacada por la violencia. Cerca de 250 jóvenes causaron todo tipo de destrozos en comercios, bancos y empresas particulares. La prensa cubrió el evento 
con todo detalle y, en general, dio la primera plana al aniversario del movimiento al día siguiente. "Rapiña y violencia en las marchas del 2 de octubre", reza el titular de El Heraldo. Muy lejos de sus espectaculares reportajes gráficos del 68 , el diario le dedicó en esta ocasión sólo diez imágenes al evento, de las cuales, nueve se focalizaron en el vandalismo de los jóvenes y sólo una cubrió el aniversario propiamente dicho, con la multitud reunida en el Zócalo capitalino. Los créditos fotográficos corrieron a cargo de Berenice Márquez, Federico Xolocotzi y Javier Arellano. Fiel a su viejo estilo, el diario omitió una reflexión de fondo, se centró en la descripción de los actos delictivos y condenó la pasividad de los cuerpos policiacos. Nada extraordinario. En su columna titulada "En privado", el conocido periodista Joaquín López Dóriga se despide del diario, y escribe la crónica que no pudo publicar 35 años antes. Describe la fila de cadáveres apilados a un costado del atrio de la iglesia de Tlatelolco, los pasillos enloquecidos del hospital Rubén Leñero, donde médicos no se daban abasto y la pila de cuerpos en el anfiteatro de la Tercera Delegación de Policía. Narra de qué manera mandó sus reportes a la dirección del diario, para que el periodista Mario Santoscoy los integrara junto con los de los demás reporteros. Señala que después de la matanza decidió ir directamente a la redacción de $E l \mathrm{He}$ raldo a las cuatro de la madrugada, se quedó dormido frente a su máquina de escribir, agotado y abatido, después de haber sido testigo de los terribles acontecimientos. Finalmente, el periodista narra su encuentro aquella mañana del 3 de octubre de 1968 con el director del periódico, Gabriel Alarcón:
[Alarcón] había llegado, como todas las mañanas, el primero, a las ocho, y como cada día, recorría la redacción, desierta como siempre a esas horas, excepto aquella mañana del 3 de octubre. Me despertó, me saludó y me preguntó. Me desperté, le saludé y le respondí. Y me dio mi plaza de reportero. $^{37}$

Ignoramos qué le habrá dicho el joven reportero a Alarcón aquella mañana. Lo que sí sabemos es la manera en que éste narró a sus lectores los acontecimientos del 2 de octubre de 1968.

\section{HEMEROGRAFÍA}

El Heraldo de México.

\section{BiBLIOGRAFÍA}

-Aguayo, Sergio, 1968: Los arcbivos de la violencia, Grijalbo/Reforma, México, 1998.

- Álvarez Garín, Raúl, La estela de Tlatelolco. Una reconstrucción bistórica del movimiento estudiantil del 68, Itaca, México, 2002.

-Bellinghausen, Hermann y Hugo Hiriart (coords.), Pensar el 68, Cal y Arena, México, 1988.

-Brocca, Victoria, Nota Roja 60's, Diana, México, 1993.

-Cano, Aurora, "Los libros y la prensa" en Silvia González (coord.), Diálogos sobre el 68, IIB-UNAM, México, 2003.

-Casanova, Rosa, Alejandro Castellanos y Rodrigo Moya, Rodrigo Moya. Fuera de moda. Obra fotográfica. 1955-1968, INAH, México, 2002.

${ }^{37}$ Joaquín López Dóriga, "En privado", El Heraldo de México, 3 de octubre de 2003, p. 11 A. 
-Espinoza, Verónica, "Las fichas de la PGR", Proceso, núm. 874, 28 de septiembre de 2003, pp. 26-30.

-García Reyes, Jaime, "Las batallas en el Politécnico" en Hermann Bellinghausen y Hugo Hiriart (coords.), Pensar el 68, Cal y Arena, México, 1988.

-González, Maricela, “Juan Guzmán en México. Fotoperiodismo, modernidad y desarrollismo en algunos de sus reportajes y fotografías de 1940 a 1960", tesis de maestría, México, Facultad de Filosofía y Letras-UNAM, 2003.

-González, Silvia, Diálogos sobre el 68, IIBUNAM, México, 2003.

-González de Alba, Luis, Las mentiras de mis maestros, Cal y Arena, México, 2002.

-Gutiérrez, Ignacio, "Los Casasola durante la posrevolución", Alquimia, núm. 1, septiembre-diciembre de 1997.

-Guevara Niebla, Gilberto, La democracia en la calle. Crónica del movimiento estudiantil mexicano, Siglo XXI, México, 1998. "Nace el movimiento" en Hermann Bellinghausen y Hugo Hiriart, Pensar el 68, Cal y Arena, México, 1988, pp. 51-59.

-Jardí, Ma. Teresa, "Así se acusó y juzgó" en Herman Bellinghausen y Hugo Hiriart (coords.), Pensar el 68, Cal y Arena, México, 1988.

-Monroy, Rebeca, Historias para ver: Enrique Diaz, fotorreportero, IIB-UNAM/INAH, México, 2003.

-Monsiváis, Carlos, "El 68: las ceremonias del agravio y la memoria" en Julio Scherer y Carlos Monsiváis, Parte de guerra II. Los rostros del 68, unAm/Nuevo Siglo Aguilar, México, 2002.
-Morales Alfonso y Mauricio Ortiz (eds.), Enrique Metinidez. El teatro de los hechos, Gobierno del Distrito Federal, México, 2000.

-Mraz, John, "Fotografiar el 68", Revista Politica y Cultura, UAM-Xochimilco, núm. 9, invierno de 1997.

$\longrightarrow$, La mirada inquieta, Centro de la Imagen, México, 1998.

_. - "Una historiografía crítica de la historia gráfica", Cuicuilco, núm. 13, mayo-agosto de 1998, pp. 77-92.

- Nacho Lopez y el fotoperiodismo mexicano en los años cincuenta, CONACULTA/INAH/ Océano, México, 1999.

-Patlagean, Evelyne, "La historia de lo imaginario" en Roger Chartier y Jacques Revel (coords.), La nueva bistoria, Mensajero, Bilbao, España, 1984.

-Ramírez, Ramón, El movimiento estudiantil de México. Ensayos y Documentos, ERA, México, 1969, 2 vols.

-Rodríguez Castañeda, Rafael, Prensa vendida, Grijalbo, México, 1993.

-Scherer, Julio y Carlos Monsiváis, Parte de guerra II. Los rostros del 68, Nuevo Siglo Aguilar/ UNAM, México, 2002.

-Volpi, Jorge, La imaginación y el poder. Una bistoria intelectual de 1968, ERA, México, 1998.

-Warman, Arturo, "Secreto de familia" en Herman Bellinghausen y Hugo Hiriart (coords.), Pensar el 68, Cal y Arena, México, 1988, p. 133.

-Zermeño, Sergio, México: una democracia utópica. El movimiento estudiantil del 68, Siglo XXI, México, 1978. 